\title{
MODELING THE SUSTAINABILITY OF LAKE TROUT FISHERIES IN EASTERN WISCONSIN WATERS OF LAKE SUPERIOR
}

by

Julie L. Nieland

\author{
A Thesis \\ submitted in partial fulfillment of the requirements of the degree \\ MASTER OF SCIENCE \\ $\mathrm{IN}$ \\ NATURAL RESOURCES (FISHERIES) \\ College of Natural Resources \\ UNIVERSITY OF WISCONSIN \\ Stevens Point, Wisconsin
}

May 2006 


\section{APPROVED BY THE GRADUATE COMMITTEE OF:}

Dr. Michael J. Hansen, Committee Chairman

Professor of Fisheries

College of Natural Resources

Dr. Tim F. Ginnett
Associate Professor of Wildlife
College of Natural Resources

College of Natural Resources

Dr. Kevin R. Russell

Assistant Professor of Wildlife Ecology and Management

College of Natural Resources

Stephen T. Schram

Lake Superior Fisheries Supervisor

Wisconsin Department of Natural Resources 


\begin{abstract}
Lake trout Salvelinus namaycush stocks in Lake Superior collapsed in the 1950s due to over-fishing and sea lamprey Petromyzon marinus predation. Stocks were rehabilitated through stocking, sea lamprey control, and fishery regulation, but concern over lake trout population sustainability still exists because commercial and recreational fishing demand is high relative to productivity and the currently-accepted $42 \%$ total annual mortality rate has not been tested for sustainability. My objective was to estimate the maximum sustainable rate of total annual mortality for lake trout in the eastern Wisconsin waters of Lake Superior. I developed a dynamic, age-structured population model to achieve this objective. The model was used to estimate mean abundance, extinction risk, and time to extinction over ranges of fishing mortality rates and commercial and recreational harvest allocations. Fishing mortality rates were varied to simulate a range of total annual mortality that encompassed the currently-accepted limit of $42 \%$. Commercial and recreational harvest were simulated independently from one another to account for different patterns of selectivity between large-mesh gill nets, the predominant commercial fishing method, and angling, the predominant recreational fishing method. Harvest of the two fisheries was simulated independently by testing commercial fishing mortality over a range of values while holding recreational fishing mortality at zero, and then testing recreational fishing mortality over a range of values while holding commercial fishing mortality at zero. Natural mortality was modeled as a combination of a fixed-base rate and a density-dependent sea lamprey induced mortality rate. Recruitment was modeled as a density-dependent function of adult lake trout abundance. Mean abundance began to decline at a fishing mortality rate of 0.20 for the
\end{abstract}


commercial fishery and 0.29 for the recreational fishery. Mean abundance began to decline at a total annual mortality rate of $42 \%$ for the commercial fishery and $47 \%$ for the recreational fishery. The risk of extinction began to increase above zero at a fishing mortality rate of 0.27 for the commercial fishery and 0.33 for the recreational fishery. The risk of extinction began to increase above zero at a total annual mortality rate of $46 \%$ for the commercial fishery and $49 \%$ for the recreational fishery. The time to extinction began to decrease at a fishing mortality rate of 0.38 for the commercial fishery and 0.49 for the recreational fishery. The time to extinction began to decrease at a total annual mortality rate of $54 \%$ for the commercial fishery and $58 \%$ for the recreational fishery. I conclude that the current total fishing mortality rate estimate of 0.025 and the current total annual mortality rate estimate of $34 \%$ are sustainable. The currently-accepted $42 \%$ total annual mortality rate also appears to be sustainable. Higher fishing and total annual mortality rates may be sustainable but should be evaluated experimentally. 


\section{ACKNOWLEDGMENTS}

Completing this project has been a challenging and rewarding experience, which would not have been possible without many people. First of all, I would like to thank Dr. Mike Hansen, my advisor, mentor, and friend, who gave me the opportunity to learn and understand more about fisheries than I expected. I am grateful for his guidance and encouragement and will never forget all he has done for me. I would like to thank Dr. Tim Ginnett and Dr. Kevin Russell for taking an interest in my project, taking time to ask and answer questions, and offering their assistance and comments. I would like to thank Steve Schram, Mike Seider, Scott Hulse, Scott Sapper, Chris Zunker, and Randy Besonen of the Wisconsin Department of Natural Resources for providing the data for this project, teaching me the history of lake trout in Lake Superior, helping me look at this project from a manager's perspective, and giving me countless opportunities to work with them on the Hack Noyes. The Wisconsin Sea Grant Institute provided funding for this project. I would also like to thank the Central Wisconsin Chapter of Trout Unlimited for additional financial support in the form of the Bill Beck Memorial Scholarship. Special thanks to Jon Deroba, Lisa Corradin, Casey Schoenebeck, Amy Schueller, Jordan Weeks, Breanna Riedel, Jennifer Hurt, Paul Bergman, Mike Hosack, Ron Bruch, and Nancy Nate for great conversations, being friends I know I can lean on, being remarkable peers to learn from, and giving me many memories to cherish. I could not have asked for better colleagues and friends throughout these last few years, and I wish you all the best. And finally, I would like to thank my family for their interest in and support of my passions in life. I would not be here without you. 


\section{TABLE OF CONTENTS}

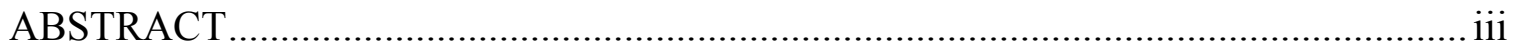

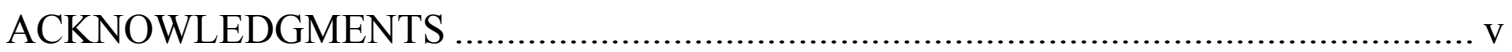

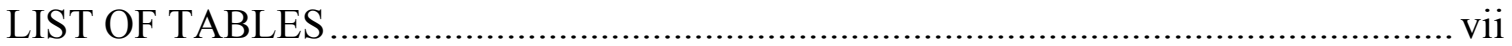

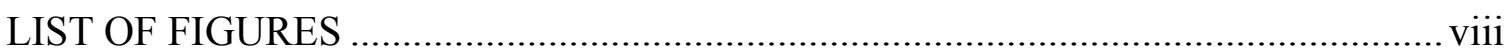

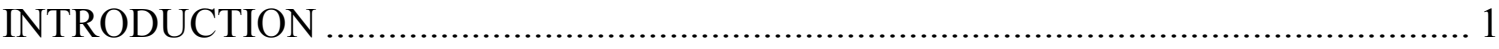

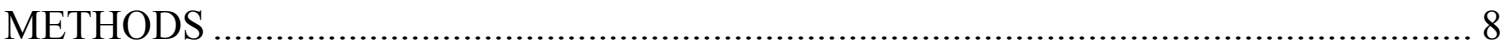

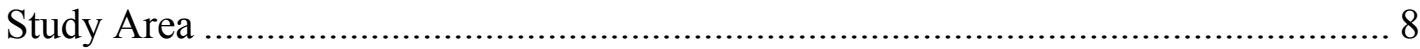

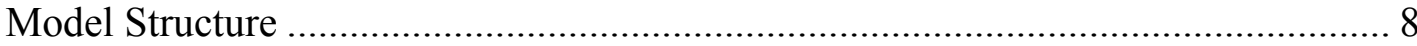

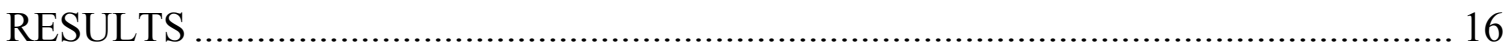

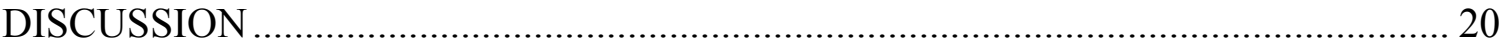

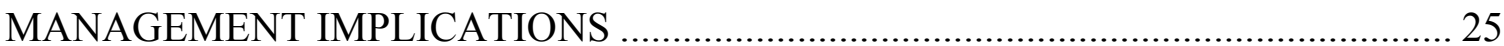

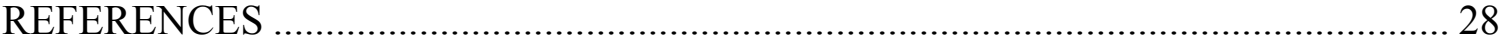




\section{LIST OF TABLES}

1. Parameters tested in local sensitivity analysis of a lake trout simulation model for eastern Wisconsin waters of Lake Superior............................................................ 39

2. Parameter tested, deviation tested, average abundance, lower and upper $95 \%$ of average abundance, and percent difference between the baseline mean and the mean for the parameter deviated for a lake trout simulation model for eastern Wisconsin waters of Lake Superior. The model was run for 1,000 simulations and 200 years for each simulation.

3. Instantaneous fishing mortality rates, $F$, and total annual mortality rates, $A$, for commercial gill-net fishing mortality and recreational angling fishing mortality when mean abundance began to decline, the probability that the population would go extinct rose above zero, and the time until the population went extinct was less than 200 years for the lake trout population in eastern Wisconsin waters of Lake Superior (iterations $=1,000$; time $=200$ years) 


\section{LIST OF FIGURES}

1. Lake trout management areas in Lake Superior. U.S. management areas are denoted by state: Michigan - MI, Minnesota - MN, and Wisconsin - WI. Canadian management areas are marked using only numbers.

2. A schematic diagram of a simulation model for lake trout in eastern Wisconsin waters of Lake Superior, where $i$ is year and $j$ is age and inputs are the total instantaneous fishing mortality rate $F_{i}$ in year $i$ and the initial abundance $N_{i j}$ in year $i$ for age $j \ldots . . .43$

3. Age-specific selectivity of sea lamprey for lake trout in eastern Wisconsin waters of Lake Superior during 1980-2004.

4. Age-specific selectivity of commercial gill-net fisheries (upper panel) and recreational angling fisheries (lower panel) for lake trout in eastern Wisconsin waters of Lake Superior during 1980-2004.

5. The relationship between instantaneous sea lamprey mortality $\left(M_{L}\right)$ on age-15-andolder lake trout and age-4-and-older lake trout abundance in eastern Wisconsin waters of Lake Superior during 1980-2004. 46

6. The relationship between the natural logarithm of instantaneous sea lamprey mortality $\left(M_{L}\right)$ on age-15-and-older lake trout and the natural logarithm of age-4-and-older lake trout abundance in eastern Wisconsin waters of Lake Superior during 1980-2004... 47

7. The relationship between number of age-4 lake trout (recruits) and age-8-and-older adult lake trout (spawners) in eastern Wisconsin waters of Lake Superior during 1980-2004. The curve depicts the fitted Ricker stock-recruitment model.

8. The relationship between the recruitment rate of age-4 lake trout $\left[\log _{\mathrm{e}}(\right.$ Recruits/Spawner)] and age-8-and-older adult lake trout abundance (spawners) in eastern Wisconsin waters of Lake Superior during 1980-2004.

9. Mean simulated abundance of age-4-and-older lake trout ( $\pm 95 \%$ confidence interval) versus commercial gill-net fishing mortality (upper panel) and recreational angling fishing mortality (lower panel) in eastern Wisconsin waters of Lake Superior (iterations $=1,000 ;$ time $=200$ years).

10. Mean simulated abundance of age-4-and-older lake trout ( $\pm 95 \%$ confidence interval) versus median total annual mortality rate for commercial gill-net fishing mortality (upper panel) and recreational angling fishing mortality (lower panel) in eastern Wisconsin waters of Lake Superior (iterations $=1,000$; time $=200$ years). 
11. Probability of extinction ( $\pm 95 \%$ confidence interval) versus commercial gill-net fishing mortality (upper panel) and recreational angling fishing mortality (lower panel) for the lake trout population in eastern Wisconsin waters of Lake Superior (iterations $=1,000 ;$ time $=200$ years $)$.

12. Probability of extinction ( $\pm 95 \%$ confidence interval) versus the median total annual mortality rate for commercial gill-net fishing mortality (upper panel) and recreational angling fishing mortality (lower panel) for the lake trout population in eastern Wisconsin waters of Lake Superior (iterations $=1,000$; time $=200$ years).

13. Time to extinction ( $\pm 95 \%$ confidence interval) versus commercial gill-net fishing mortality (upper panel) and recreational angling fishing mortality (lower panel) for the lake trout population in eastern Wisconsin waters of Lake Superior (iterations = 1,000 ; time $=200$ years)

14. Time to extinction ( $\pm 95 \%$ confidence interval) versus the median total annual mortality rate for commercial gill-net fishing mortality (upper panel) and recreational angling fishing mortality (lower panel) for the lake trout population in eastern Wisconsin waters of Lake Superior (iterations $=1,000$; time $=200$ years). 


\section{INTRODUCTION}

Lake trout Salvelinus namaycush were historically important in the Great Lakes as native predators in the fish community and as a predominant species in the fishing industry. Native Americans first harvested lake trout for subsistence and trade, and Europeans developed commercial and recreational fisheries as they settled the Great Lakes basin in the late 1700s and early 1800s (Lawrie and Rahrer 1972; Goodier 1989; Hansen 1999). Fisheries began in the lower lakes, Ontario and Erie, and extended to the upper lakes, Huron, Michigan, and Superior, as European colonization of the area continued (Hansen 1999). Commercial fisheries expanded through the process of fishing up, in which effort is shifted to previously unexploited grounds as stocks are depleted (Lawrie and Rahrer 1972; Goodier 1989; Hansen et al. 1995). Beginning in the late 1800s, advances in technology, including steam tugs, motor boats, hydraulic gill-net lifters, and nylon gill nets, made harvest more efficient. Lake trout abundance was already reduced in Lake Ontario and Lake Erie by 1900, then rebounded slightly in the 1920s, only to collapse in the 1930s and 1940s (Christie 1973; Cornelius et al. 1995; Elrod et al. 1995). Lake trout abundance was also declining in the upper lakes, but yield was sustained through increased fishing effort (Hile et al. 1951; Pycha and King 1975) until 1935 in Lake Huron, 1943 in Lake Michigan, and 1950 in Lake Superior (Baldwin et al. 1979).

The invasion of sea lampreys Petromyzon marinus put even more strain on the already troubled lake trout stocks. Sea lampreys were not recorded in Lake Ontario until 1835, but the completion of the Welland Canal between Lake Ontario and Lake Erie in 1829 allowed sea lampreys access to the rest of the Great Lakes, which they colonized by 
the early 1940s (Pearce et al. 1980; Smith 1995). The combination of overfishing and sea lamprey predation drove lake trout to extirpation by 1962 in all of the Great Lakes except remote areas in Lake Huron and Lake Superior (Berst and Spangler 1973; Lawrie 1978; Pycha 1980).

Many lake trout morphotypes once existed, but high fishing pressure led to the disappearance of all but three of the morphotypes in the Great Lakes (Pycha and King 1975; Goodier 1981). The lean lake trout, the siscowet or fat lake trout, and the humper or banker lake trout are the remaining forms, of which the siscowet and humper are only found in Lake Superior (Khan and Qadri 1970; Lawrie and Rahrer 1973; Pycha and King 1975; Burnham-Curtis and Smith 1994). Lean lake trout are slender with the lowest body fat content, have straight, pointed snouts, and generally inhabit depths less than $73 \mathrm{~m}$ (Lawrie and Rahrer 1973). In Lake Superior, 50\% of female lean lake trout are sexually mature by age 8 (Peck and Sitar 2000), and spawning occurs from October to early November on rocky substrate in 15-30 m of water around the mainland or islands (Eschmeyer 1955; Pycha and King 1975; Peck 1986; Burnham-Curtis and Smith 1994). Leans are also known to spawn in deeper offshore reefs (Hansen et al. 1995). Siscowet lake trout are deep-bodied with the highest body fat content, have short heads and blunt snouts, and generally inhabit waters 50-150 m deep (Lawrie and Rahrer 1973; Pycha and King 1975). Siscowets have been found in spawning condition from April through November (Eschmeyer 1955; Goodier 1981; Bronte 1993). Humper lake trout have deep bodies, blunt snouts, large eyes, thin abdominal walls, intermediate body fat content, and inhabit isolated shoals, about $50 \mathrm{~m}$ deep, surrounded by water greater than $100 \mathrm{~m}$ deep (Khan and Qadri 1970; Lawrie and Rahrer 1973; Burnham-Curtis and Smith 1994). 
Humpers spawn on offshore reefs between August and October (Burnham-Curtis and Smith 1994).

Before lake trout stocks were completely eradicated in the Great Lakes, fishery managers took steps to preserve and revive remaining lake trout stocks. Because a few lake trout still survived in Lake Superior, a rehabilitation plan was developed first for that lake. Rehabilitation efforts focused on the lean lake trout because commercial and recreational lake trout fisheries targeted this morphotype. The Lake Superior Technical Committee (LSTC), which is comprised of fishery researchers and managers from numerous fishery management agencies, developed objectives to manage the fish community (Busiahn 1990; Horns et al. 2003), including goals for lake trout rehabilitation (LSLTTC 1986; Hansen 1996). The goals were to restore recruitment, reduce total mortality, and sustain reproducing lake trout stocks capable of supporting annual yields of 2-million $\mathrm{kg}$ (LSLTTC 1986). The strategy was to increase recruitment by stocking hatchery-reared lean lake trout and to reduce mortality by controlling sea lamprey abundance and regulating fisheries. Progress toward these goals and objectives was reported in state of the lake reports (Hansen 1990, 1994).

Rehabilitation began with the stocking of fin-clipped lake trout fingerlings into Ontario waters of Lake Superior in 1947 and fingerlings and yearlings into U.S. waters in 1951 (Lawrie and Rahrer 1972, 1973; Lawrie 1978; Hansen et al. 1995). Fish were finclipped on a 5-year rotation of the adipose, pelvic, and pectoral fins to identify their hatchery origin and to distinguish year-classes. Numbers of lake trout planted into Lake Superior increased throughout the 1950s, and hatchery fish accounted for $98 \%$ of inshore stocks by the end of the 1960s (Lawrie and Rahrer 1972; Pycha and King 1975). 
Sea lamprey control was used to reduce total annual mortality on lake trout stocks. Weirs were first employed in 1953 to block streams where adult sea lampreys spawned (Smith et al. 1974). However, sea lamprey control was not effective until 1958 when the selective lampricides 3-trifluoromethyl-4-nitrophenol (TFM) and 2'5-dichloro-4'nitrosalicylanilide (Bayer 73) were developed to kill larvae where they resided in streams for 4-6 years before transforming into parasitic adults (Smith et al. 1974). Chemical treatment of spawning streams helped reduce sea lamprey abundance by $86 \%$ in 1962 (Smith et al. 1974). In recent decades, release of sterile-male sea lampreys has been used to supplement chemical control (Hanson and Manion 1978, 1980), and sea lamprey pheromones are also being studied to increase trapping efficiency (Johnson et al. 2005).

Fishery regulations were used to limit the fishing mortality component of total annual mortality. Fisheries for lake trout were closed in 1962 to give lake trout a reprieve from fishing pressure (Pycha and King 1975). However, management agencies reopened restricted recreational and commercial fisheries as lake trout stocks began to recover, and regulations were applied inconsistently among jurisdictions, so fishing mortality rates climbed once again (Hansen et al. 1995). Commercial fishing mortality was reduced by limiting the number of licenses issued and the amount of gear, mesh sizes, fish sizes, seasons, areas, and depths that could be fished (Hansen et al. 1995). Recreational fishing mortality was reduced by minimum length limits and daily bag limits, and anglers were required to purchase a license to fish on the Great Lakes (Hansen et al. 1995). In Wisconsin waters, refuges were designated to protect spawning lake trout around Gull Island Shoal in 1976 (Swanson and Swedberg 1980) and Devils Island Shoal in 1981 (Hansen et al. 1995). Healey (1978) concluded that lake trout populations were self- 
sustaining when total annual mortality was less than or equal to $50 \%$ but declined rapidly when total annual mortality was greater than 50\%. In response to Healey's (1978) study, the LSTC charged agencies with limiting lake trout harvest to reduce total annual mortality rates to $50 \%$ or less to allow lake trout to survive until they became sexually mature and could reproduce (LSLTTC 1986). The LSTC suggested that the 114-mm mesh gillnets (also known as large-mesh gill nets) used in commercial and assessment fisheries are size-selective and likely overestimate the total annual mortality rate, so a $50 \%$ mortality rate estimated from $114-\mathrm{mm}$ mesh gillnets is roughly equivalent to a $42 \%$ actual mortality rate (LSLTTC 1986). Therefore, the LSTC set the sustainable limit of total annual mortality at $42 \%$ (LSLTTC 1986).

Results of rehabilitation efforts varied among jurisdictions and areas of the lake. Abundance of wild lake trout from unknown parentage generally increased during 1970 1992 (Hansen 1990; Hansen et al. 1994b), but abundance of stocked lake trout decreased in spite of relatively consistent stocking rates (Hansen et al. 1994a, 1994b). An early stock-recruitment analysis indicated that stocked lake trout contributed to recruitment more than wild lake trout (Hansen et al. 1995), but subsequent studies indicated that wild and stocked lake trout contributed equally to recruitment in Michigan waters (Richards et al. 2004) and only wild lake trout contributed to recruitment in Wisconsin and Minnesota waters (Corradin 2004). Hansen et al. (1996) determined that survival of the 1963-1986 year-classes of stocked lake trout was limited by large-mesh gill-net fishing effort in Michigan and Wisconsin waters and by wild lake trout predation in Minnesota waters. Richards et al. (2004) concluded that large-mesh gill-net fishing effort during 1970-1998 did not substantially limit survival of wild lake trout in Michigan waters. The results of 
these two studies likely differed because Hansen et al. (1996) studied survival of stocked lake trout, whereas Richards et al. (2004) studied survival of wild lake trout. The results of the two studies also likely indicate that catchability of stocked and wild lake trout differ, possibly due to differences in bathymetric distribution (Krueger et al. 1986). Further analysis of historic and modern lake trout abundance in Michigan waters indicated that wild lake trout stocks were more abundant during 1984-1998 than during 1929-1943 (Wilberg et al. 2003).

These studies suggested that lake trout rehabilitation had progressed far enough to cease stocking, as long as fisheries were effectively regulated. Stocking was halted in most areas of Lake Superior by March of 1996 because lake trout rehabilitation goals had been met. Fisheries must be regulated because lake trout are still in high demand in commercial and recreational fisheries. Stock abundance must be accurately estimated to set harvest quotas, which are divided among state agencies and several Lake Superior Bands of Chippewa Indians. Agencies currently use statistical catch-at-age (SCAA) models to develop quotas without knowing if the currently-accepted $42 \%$ total annual mortality rate is sustainable. Models are needed in the short-term to predict stock sizes in the next year and in the long-term to estimate a sustainable level of fishing mortality and to simulate stock reactions to different management actions, including total allowable catch limits, gear restrictions, size limits, and fishery allocations.

My objective was to estimate the maximum sustainable fishing and total annual mortality rates for lake trout in eastern Wisconsin waters of Lake Superior to help better manage the fishery and to minimize the risk of overexploitation. I developed an agestructured, density-dependent, simulation model to fulfill this objective. The model 
focused specifically on the lean lake trout morphotype because lean lake trout are the most highly sought by fisheries and the most marketable because of their low body fat content. Natural mortality was modeled as a fixed-base rate and a density-dependent sea lamprey mortality rate. Recruit abundance was modeled as a density-dependent function of adult lake trout abundance. Random process error was incorporated into sea lamprey mortality and recruitment sub-models to simulate model uncertainty. The model was used to simulate long-term effects of various commercial and recreational harvest allocations. Commercial fisheries rely on large-mesh gill nets and recreational fisheries rely on angling, which differ in size selectivity. Fishing mortality rates were varied to simulate a range of total annual mortality that included the currently-accepted $42 \%$ total annual mortality rate. 


\section{METHODS}

\section{Study Area}

Lake Superior has the largest surface area of any freshwater lake in the world $\left(82,414 \mathrm{~km}^{2}\right)$, is second only to Lake Baikal in volume $\left(11,920 \mathrm{~km}^{3}\right)$, and contains $10 \%$ of the world's surface fresh water and over half of the water in the Great Lakes (Matheson and Munawar 1978). Lake Superior is highly oligotrophic due to its low mean temperature $\left(6^{\circ} \mathrm{C}\right.$; Bennett 1978), low dissolved solids $(60 \mathrm{mg} / \mathrm{L}$; Weiler 1978), great depth (148 m mean and 406 m maximum; Lawrie and Rahrer 1973), and low primary productivity (1.6-5.6 $\mathrm{mgC} / \mathrm{m}^{3} / \mathrm{hr} / \mathrm{mo}$; Munawar and Munawar 1978). Water replacement time in Lake Superior is 191 years (Horns et al. 2003).

The U.S. and Canadian waters of Lake Superior are divided into lake trout management areas (Figure 1). My study focused on the eastern Wisconsin management unit known as WI2, which has a surface area of $4,474 \mathrm{~km}^{2}$ and includes the 22 Apostle Islands. The rocky shoals of the Apostle Islands provide spawning habitat for lake trout. Spawning lake trout are protected in two refuges, the Gull Island Shoal refuge, which has

a surface area of $336 \mathrm{~km}^{2}$, and the Devils Island Shoal refuge, which has a surface area of $283 \mathrm{~km}^{2}$. No commercial or recreational fishing is permitted in the refuges.

\section{Model Structure}

A simulation model was built to predict lake trout abundance in the eastern Wisconsin waters of Lake Superior in future years. The simulation model was parameterized from SCAA model estimates for wild lake trout in non-refuge portions of eastern Wisconsin waters of Lake Superior. The SCAA model was used to estimate 
recreational and commercial fishery harvest, abundance-at-age, age-specific mortality, year-specific mortality, gear selectivity, catchability, and assessment catch per unit effort (CPE) for age-4-and-older lake trout during 1980-2001 (Linton 2002). The Wisconsin Department of Natural Resources (WDNR) subsequently updated the SCAA model through 2004 (Wisconsin State/Tribal Technical Committee 2005).

Initial abundance $N_{i j}$ at age $j$ for year $i=0$ for the simulation model was derived from age-specific wild lake trout abundance estimates from the SCAA model for 2004. In each simulation, age-specific abundance estimates from 2004 were an input for year zero and were used to predict abundance at age for the next year:

$$
N_{i+1, j+1}=N_{i j} e^{-Z_{i j}} ;
$$

where $N_{i+1, j+1}$ is the number of lake trout surviving in each age class $j$ and year $i$ to the next age class $j+1$ and year $i+1, N_{i j}$ is the number of lake trout in age class $j$ in year $i$, and $Z_{i j}$ is the total instantaneous mortality rate for each age class $j$ in year $i$ (Quinn and Deriso 1999; Haddon 2001; Figure 2). The total instantaneous mortality rate $Z_{i j}$ for each age class $j$ and year $i$ was the summation of the total instantaneous natural mortality rate $M$, the instantaneous sea lamprey mortality rate $M_{L i j}$ for age class $j$ in year $i$, and the total instantaneous fishing mortality rate $F_{i j}$ for age class $j$ in year $i$ :

$$
Z_{i j}=M+M_{L i j}+F_{i j} .
$$

The total instantaneous natural mortality rate was previously estimated as a constant over all ages and years in the SCAA model $(M=0.1649$; Linton 2002; 
Wisconsin State/Tribal Technical Committee 2005). Instantaneous sea lamprey mortality was modeled as a density-dependent function of lake trout abundance:

$$
M_{L i, j=15+}=\alpha N_{i, j=4+}^{-\beta} e^{\varepsilon}
$$

where $M_{L i, j=15+}$ is the total instantaneous sea lamprey mortality on age-15-and-older lake trout, $\alpha$ is the instantaneous sea lamprey mortality rate when lake trout abundance is zero, $N_{i, j=4+}$ is the number of age-4-and-older lake trout in year $i, \beta$ is the exponential rate at which instantaneous sea lamprey mortality declines with lake trout abundance, and $\varepsilon$ is the multiplicative process error. A negative power function was used for the submodel of instantaneous sea lamprey mortality because lake trout abundance varies, whereas sea lamprey abundance is limited. Sea lampreys are held at a fixed adult abundance by population control, so the ratio of sea lampreys to lake trout rises exponentially as lake trout numbers decline. Instantaneous sea lamprey mortality on age15-and-older lake trout was used as the fully-selected sea lamprey mortality rate because sea lamprey have been shown to select larger, older fish to prey upon (Swink 1991, 2003), and age-15-and-older was the oldest age-class of lake trout included in the model. The parameters $\alpha$ and $\beta$ were estimated from the linear version of the model:

$$
\log _{e}\left(M_{L i, j=15+}\right)=\log _{e}(\alpha)-\beta \log _{e}\left(N_{i, j=4+}\right)+\varepsilon
$$

The model was fit to 1980-2004 SCAA model estimates of fully-selected sea lamprey mortality and age-4-and-older lake trout abundance. The natural logarithm of the instantaneous sea lamprey mortality rate on age-15-and-older lake trout was lagged by one year to avoid a circular reference in the data analysis. For example, the natural logarithm of age-4-and-older lake trout abundance from 1980 was used to explain 
variation in the natural logarithm of the fully-selected sea lamprey mortality from 1981. The total instantaneous sea lamprey mortality for younger ages of lake trout was then estimated by multiplying the fully-selected sea lamprey mortality rate by the relative sea lamprey mortality rate from 1980-2004 for each age class $j$ (Figure 3). Error $\varepsilon$ was estimated as variation in the natural logarithm of the instantaneous rate of sea lamprey mortality on age-15-and-older lake trout that was not explained by the natural logarithm of age-4-and-older lake trout.

The total instantaneous fishing mortality rate $F_{i j}$ of age $j$ lake trout in year $i$ was separated into components for commercial $F_{C i j}$ and recreational $F_{R i j}$ fisheries:

$$
F_{i j}=F_{C i j}+F_{R i j} \text {. }
$$

Total instantaneous fishing mortality $F_{i j}$ of age $j$ lake trout in year $i$ was an input in the model and was simulated using age-specific selectivity curves for each fishery that were previously estimated in the SCAA model. For the commercial gill-net fishery, instantaneous fishing mortality $F_{C i j}$ of age class $j$ in year $i$ was the product of the fullyselected instantaneous fishing mortality rate $F_{C i}$ in year $i$ and the relative selectivity $s_{C j}$ of age class $j$ :

$$
F_{C i j}=s_{C j} F_{C i}
$$

where $s_{C j}$ was the relative selectivity of large-mesh gill nets for age class $j$ :

$$
S_{C j}=\frac{1}{1+e^{-b_{2}\left(j-b_{1}\right)}}\left(1-\frac{1}{1+e^{-b_{4}\left(j-b_{3}\right)}}\right) \text {; }
$$


where $b_{1}$ is the first inflection point of the selectivity curve, $b_{2}$ is the first slope, $b_{3}$ is the second inflection point, $b_{4}$ is the second slope, and $j$ is the age class (Linton 2002). The selectivity curve was standardized to the maximum estimated selectivity. For the recreational angling fishery, total instantaneous fishing mortality rate $F_{R i j}$ and angling selectivity $s_{R j}$ were estimated in the same manner. Large-mesh gill net and angling selectivity curves were previously estimated (Linton 2002; Wisconsin State/Tribal Technical Committee 2005; Figure 4).

Next, the number of recruits was predicted using a Ricker stock-recruitment model (Ricker 1975):

$$
N_{i, j=4}=\alpha\left(N_{i, j=8+}\right)\left(e^{-\beta N_{i, j=8+}}\right) e^{\varepsilon} ;
$$

where $N_{i, j=4}$ is the number of age- 4 lake trout to enter into the population in year $i, \alpha$ is the number of recruits produced by each spawning adult lake trout at low population abundance, $N_{i, j=8+}$ is the parental abundance of age- 8 -and-older lake trout in year $i, \beta$ is the instantaneous decline in recruitment as parental abundance increases, and $\varepsilon$ is multiplicative process error. Age-4 lake trout were used to index recruitment because age-4 is the first age-class when lake trout are recruited to large-mesh gill nets. Age-8and-older lake trout were used to index spawning stock density because $50 \%$ of female lake trout in Lake Superior reached sexual maturity by age 8 (Peck and Sitar 2000). Stocked lake trout were not included in spawning stock density because they were previously found to have no effect on recruitment in WI2 (Corradin 2004). Model parameters $\alpha$ and $\beta$ were estimated from the linear form of the model: 


$$
\log _{e}\left(\frac{N_{i, j=4}}{N_{i, j=8+}}\right)=\log _{e}(\alpha)-\beta N_{i, j=8+}+\varepsilon
$$

where $\log _{e}\left(\frac{N_{i, j=4}}{N_{i, j=8+}}\right)$ is the natural logarithm of recruits per spawner and other terms are as defined for the nonlinear version of the model. The linear stock-recruitment model was fit to 1980-2004 SCAA model estimates of age-4 lake trout abundance and age-8and-older lake trout abundance. A five-year lag exists between the time when age-8-andolder lake trout spawn and age-4 lake trout are recruited to large-mesh gill nets, so, for example, age-8-and-older abundance from 1980 was used to predict age-4 abundance from 1985. Residual error $\varepsilon$ was estimated as variation in the natural logarithm of recruits per spawner that was not explained by spawner abundance.

The model was evaluated using local sensitivity analysis. This method is frequently used to quantify uncertainty in simulation models and to determine which model parameters have the most influence on model predictions (McCarthy et al. 1996; Cross and Beissinger 2001; Ellner and Fieberg 2003; Essington 2003). A local sensitivity analysis was performed by holding each parameter at a constant value while changing one parameter at a time by $\pm 10 \%$ (Table 1; Essington 2003). The sensitivity to a parameter was expressed as the difference in the mean population abundance when the parameter was changed, compared to the mean population abundance when all parameters were set at their 2004 estimates from the SCAA model. Highly sensitive parameters caused the mean population abundance to deviate by more than $10 \%$, linearly sensitive parameters caused the mean population abundance to deviate by $10 \%$, and insensitive parameters caused the mean population abundance to deviate by less than 
$10 \%$ (Essington 2003). The model was run 1,000 times for 200 years for each parameter deviation. Mean lake trout abundance was calculated as the average abundance of age-4and-older lake trout from year 51 to year 200 for each simulation.

Instantaneous commercial and recreational fishing mortality were simulated separately to cover the two extremes possible for fishing mortality. Therefore, any mixed allocation of the two fisheries would fall between the two extremes of each fishery alone. Simulations were run in this manner to account for differences in selectivity between large-mesh gill nets used in the commercial fishery and angling used in the recreational fishery. First, recreational fishing mortality $F_{R i}$ was held at zero while the commercial fishing mortality $F_{C i}$ was tested over a range of values. Then, commercial fishing mortality was held at zero while the recreational fishing mortality was tested over a range of values. A range of fishing mortality rates was tested for each fishery to encompass the maximum sustainable total instantaneous fishing mortality rate. For each simulated recreational and commercial fishing mortality, the total annual mortality $A$ was calculated:

$$
A=1-e^{-Z_{i j}} .
$$

The range of total annual mortality rates tested included the currently-accepted $42 \%$ total annual mortality rate (LSLTTC 1986). Simulations were run 1,000 times for 200 years each to test values.

Mean abundance, probability of extinction, and time to extinction were the metrics used to evaluate sustainability of total instantaneous fishing mortality and total annual mortality rates. Mean abundance was the average abundance of age-4-and-older lake trout from year 51 to year 200 for all simulations. A population was considered to 
go extinct in the first year when age-4-and-older abundance equaled zero. Zero abundances were included in the average. A 95\% confidence interval was calculated for mean lake trout abundance:

$$
\bar{x} \pm s * 1.96
$$

where $\bar{x}$ is the average lake trout abundance and $s$ is the standard deviation of lake trout abundance for the sample. The probability of extinction was the proportion of 1,000 simulations when the abundance declined to zero. A 95\% confidence interval was calculated for the probability of extinction using the exact upper and lower $95 \%$ confidence limits for a binomial proportion (Zar 1999). The time to extinction was the median number of years until age-4-and-older lake trout abundance declined to zero. Simulations that did not result in an extinction event were assigned an extinction time of 200 years because the lake trout population was assumed to go extinct after the 200 years included in the model. A $95 \%$ confidence interval was calculated for the time to extinction as the 2.5-percentile and the 97.5-percentile of the time to extinction for the 1,000 simulations. 


\section{RESULTS}

Instantaneous sea lamprey mortality on age-15-and-older lake trout was a density dependent function of age-4-and-older lake trout abundance:

$$
M_{L i, j=15+}=2,935,453 N_{i, j=4+}^{-1.178245} e^{0.42}
$$

where $2,935,453$ was the fully-selected sea lamprey mortality rate when lake trout abundance was zero, 1.178245 was the exponential rate of decrease in the fully-selected sea lamprey mortality as lake trout abundance increased, and 0.42 was multiplicative process error in the instantaneous sea lamprey mortality rate (Figure 5). The natural logarithm of age-4-and-older lake trout abundance explained $58 \%$ of the variation in the natural logarithm of the fully-selected sea lamprey mortality rate $\left(F_{1,22}=29.89 ; P \leq 0.001\right.$; Figure 6).

Recruitment of age-4 lake trout was a density dependent function of age-8-andolder lake trout abundance:

$$
N_{i, j=4}=5.6984\left(N_{i, j=8+}\right)\left(e^{-0.0000032348 N_{i, j=8+}}\right) e^{0.20}
$$

where 5.6984 was the number of age- 4 recruits produced by each age- 8 -and-older adult lake trout when adult abundance was low, 0.0000032348 was the instantaneous rate of decline in the recruitment rate as adult abundance increased, and 0.20 was the variation in the natural logarithm of recruits per spawner that was not explained by adult lake trout abundance (Figure 7). Abundance of age-8-and-older adult lake trout explained $80 \%$ of the variation in the natural logarithm of age- 4 recruits per adult lake trout $\left(F_{1,18}=73.19\right.$; $P \leq 0.001 ;$ Figure 8) 
The local sensitivity analysis indicated lake trout abundance was most sensitive to the sea lamprey mortality slope and intercept parameters and the recruitment densitydependent parameter. The mean lake trout population abundance decreased by more than $10 \%$ when the sea lamprey mortality slope parameter was reduced by $10 \%$ and the sea lamprey mortality intercept parameter was increased by $10 \%$, so these parameters were highly sensitive (Table 2). The recruitment model density-dependent parameter was linearly sensitive because $\pm 10 \%$ deviations in the parameter caused $10 \%$ deviations in the mean population abundance of lake trout (Table 2). Other parameters tested were insensitive parameters because they caused less than a 10\% deviation in the mean population abundance of lake trout when the parameter was deviated by $\pm 10 \%$ (Table 2 ).

Mean lake trout population abundance increased as total instantaneous fishing mortality and total annual mortality increased, and then declined when instantaneous fishing mortality and total annual mortality increased further. For commercial fishing mortality, mean lake trout abundance increased as instantaneous fishing mortality increased from zero to 0.20 , and then declined to zero when instantaneous fishing mortality rate increased from 0.20 to 0.50 (Table 3 ; Figure 9). Mean lake trout abundance increased as total annual mortality rate with only commercial fishing mortality increased to $42 \%$ and then declined to zero as the total annual mortality rate increased further (Table 3; Figure 10). For recreational fishing mortality, mean population abundance increased as instantaneous fishing mortality increased from zero to 0.29 , and then declined thereafter (Table 3; Figure 9). Mean lake trout population abundance increased as total annual mortality rate with only recreational fishing mortality increased 
from zero to $47 \%$ and then decreased as total annual mortality increased further (Table 3; Figure 10).

The probability of extinction was zero until threshold levels of fishing and total annual mortality were reached and then increased quickly to 1.0 as mortality increased further. For commercial fishing mortality, the probability of extinction began to rise above zero at an instantaneous fishing mortality rate of 0.27 , reached 0.5 at a fishing mortality rate of 0.39 , and reached 1.0 at a fishing mortality rate of 0.45 (Table 3; Figure 11). The probability of extinction began to rise above zero at a $46 \%$ total annual mortality rate with only commercial fishing and reached 0.5 at a $100 \%$ total annual mortality rate (Table 3; Figure 12). For recreational fishing mortality, the probability of extinction began to rise above zero at an instantaneous fishing mortality rate of 0.33 , reached 0.5 at a fishing mortality rate of 0.50 , and reached 1.0 at a fishing mortality rate of 0.58 (Table 3; Figure 11). The probability of extinction began to rise above zero at a $49 \%$ total annual mortality rate with only recreational fishing mortality, reached 0.5 at a total annual mortality rate of $99 \%$, and reached 1.0 at a total annual mortality rate of 100\% (Table 3; Figure 12).

The time to extinction remained at 200 years until threshold levels of fishing and total annual mortality were reached and then quickly declined toward zero as mortality increased further. For commercial fishing mortality, the time to extinction started to decline below 200 years at an instantaneous fishing mortality rate of 0.38 , decreased rapidly from 0.38 to 0.39 , and declined more slowly as instantaneous fishing mortality increased further (Table 3; Figure 13). The time to extinction began to decline below 200 years at a $54 \%$ total annual mortality rate with only commercial fishing mortality and 
decreased rapidly as total annual mortality increased from $54 \%$ to $100 \%$ (Table 3; Figure 14). For recreational fishing mortality, the time to extinction started to decline below 200 years at an instantaneous fishing mortality rate of 0.49 , decreased rapidly from 0.49 to 0.50 , and declined more slowly as instantaneous fishing mortality increased further (Table 3; Figure 13). The time to extinction began to decline below 200 years at a $58 \%$ total annual mortality rate with only recreational fishing mortality and decreased rapidly as total annual mortality increased from $58 \%$ to $100 \%$ (Table 3; Figure 14). 


\section{DISCUSSION}

I found that fully-selected sea lamprey mortality decreased as lake trout abundance increased, which suggests a Type-II functional response between sea lamprey and lake trout in Lake Superior (Holling 1959a). Kitchell and Breck (1980) previously hypothesized that sea lamprey mortality would decrease as host density increased in the Great Lakes because sea lampreys could act as predators when host abundance was low and switch to parasitism when host abundance was high. The rate at which individual sea lamprey attack lake trout likely increases with host density, but the feeding rate likely reaches a maximum at high prey densities (Gotelli 2001; Bence et al. 2003). A predator may kill more individuals as prey density increases, but the proportion of the prey population killed by the predator decreases as prey density increases because the predator reaches the maximum feeding rate (Solomon 1949; Gotelli 2001). Similarly, the proportion of caribou Rangifer tarandus killed by wolves Canis lupis in northern Alaska (Dale et al. 1994) and the proportion of moose Alces alces killed by wolves in North America (Messier 1994) decreased as prey density increased. A Type-II functional response was exhibited in these systems because predator density was constant (Holling 1959b). Wolf density was self-regulated by the animals' territorial behavior, whereas sea lamprey density was controlled by humans.

I found that lake trout recruitment in WI2 was density dependent during 19802004. In contrast to my findings, Bronte et al. (1995) and Schram et al. (1995) found that adult lake trout abundance was linearly related to recruit abundance in WI2 during 19641992, which suggested that recruitment was density independent. Similar to my findings, Corradin (2004) found that lake trout recruitment in WI2 was a density dependent 
function of adult lake trout abundance during 1980-2003. These studies were likely contradictory because lake trout abundance increased substantially after the last year studied by Bronte et al. (1995) and Schram et al. (1995) and thereby increased the likelihood that recruitment would exhibit density dependence during the period studied by Corradin (2004), as Richards et al. (2004) found in Michigan waters of Lake Superior, where lake trout density was much higher than in Wisconsin waters.

Mean lake trout abundance in WI2 began to decrease at an instantaneous fishing mortality rate of 0.20 for gill-netting and 0.29 for angling, which was similar to Rago et al. (1998), who estimated that $F_{\text {replacement }}=0.25$ with an $84 \mathrm{~cm}$ minimum length limit for spiny dogfish Squalus acanthias in the northwest Atlantic Ocean. Similarly, porbeagle Lamna nasus populations declined at $F=0.18$ in the Atlantic Ocean (Campana et al. 2002). Both of these species, like lake trout, are long lived and late maturing, so have similar maximum sustainable fishing mortality rates. In contrast, the Eastern Baltic Sea cod Gadus morhua callarias stock increased up to a higher instantaneous fishing mortality rate ( $F=0.32$; Radtke 2003), possibly because cod are earlier maturing and shorter lived than lake trout, spiny dogfish, or porbeagle.

Mean lake trout abundance in WI2 began to decrease at a total annual mortality rate of $42 \%$ with only commercial fishing mortality and $47 \%$ with only recreational fishing mortality, which is similar to what Healey (1978) found for lake trout in Canadian lakes that were able to sustain populations at a total annual mortality rate of $50 \%$ or less. A population viability analysis of Gulf of Mexico sturgeon Acipenser oxyrinchus desotoi in the Suwannee River, Florida, predicted that a $16 \%$ total annual mortality rate would be sustainable but an increase to $20 \%$ would cause a decline in abundance (Pine et al. 2001). 
Gulf of Mexico sturgeon abundance likely declined at lower total annual mortality rates than lake trout in WI2 because sturgeon do not reproduce every year after reaching maturity, and they live longer and grow slower than lake trout. My results suggest that the $42 \%$ total annual mortality rate limit in the Lake Superior lake trout rehabilitation plan is sustainable (LSLTTC 1986). Although lake trout abundance in the model began to decline at a $42 \%$ total annual mortality rate with only commercial fishing mortality, a $42 \%$ total annual mortality rate with a combination of commercial and recreational fishing mortality should be sustainable because commercial fishing mortality will need to be lower than 0.20 and recreational fishing mortality will need to be lower than 0.29 to produce a combined $42 \%$ total annual mortality rate.

The risk of extinction for the lake trout population in WI2 began to increase above zero at an instantaneous fishing mortality rate of 0.27 for gill-netting and 0.33 for angling. My findings indicate that lake trout in WI2 are not able to sustain total instantaneous fishing mortality rates as high as Pacific hake Merluccius productus $\left(F_{\mathrm{CRIT}}=1.11-1.27\right.$, where $F_{\text {CRIT }}$ is the maximum sustainable fishing mortality rate to avoid stock collapse; Brodziak 2002), perhaps because Pacific hake are shorter lived, faster growing, and earlier maturing than lake trout. Conversely, lake trout were able to sustain higher rates of instantaneous fishing mortality than longer-lived, slower-growing, lower-fecundity species like Dover sole Microstomus pacificus $(F=0.15)$, lingcod Ophiodon elongatus $(F=0.08)$, sablefish Anoplopoma fimbria $(F=0.05)$, and widow rockfish Sebastes entomelas $(F=0.08)$ in the Pacific Ocean (Brodziak 2002), and for the porbeagle in the Atlantic Ocean $(F=0.08)$, where $F$ was the instantaneous fishing mortality rate where the population could still replace itself and avoid stock collapse (Campana et al. 2002). These 
species take a longer time to replace themselves than lake trout, which may explain why they are not able to withstand as much fishing pressure as lake trout.

The risk of extinction began to increase above zero at a total annual mortality rate of $46 \%$ with only commercial fishing mortality and $49 \%$ with only recreational fishing mortality. Lake trout in WI2 were not able to sustain as high a total annual mortality rate as northern pike Esox lucius in Camerton Lake in north-central Minnesota $(A=63 \%)$, perhaps because northern pike mature earlier, generally at age 3 , and are faster growing and shorter lived than lake trout (Pierce et al. 2003). Conversely, lake trout in WI2 were able to sustain a higher total annual mortality rate than paddlefish Polyodon spathula in the Missouri River ( $A=18 \%$; Rosen et al. 1982), perhaps because paddlefish are longer lived, mature later in life (age 16, twice as long as lake trout), and do not reproduce every year after reaching maturity.

Time to extinction fell below 200 years at an instantaneous mortality rate of 0.38 and a total annual mortality rate of $54 \%$ with only commercial fishing mortality and an instantaneous mortality rate of 0.49 and a total annual mortality rate of $58 \%$ with only recreational fishing mortality. Mean lake trout abundance at these fishing mortality rates was already declining. Like my study, a population viability analysis for the Florida manatee Trichechus manatus latirostris showed that the time to extinction decreased as the population declined due to increased mortality (Marmontel et al. 1997). Similarly, the time to extinction of the Balearic shearwater Puffinus mauretanicus population in the Mediterranean archipelago decreased as the number of breeding females decreased (Oro et al. 2004). 
I found that the total annual mortality rate of lake trout increased sharply when commercial and recreational fishing mortality rates increased only slightly above certain threshold levels. For commercial fishing mortality, total annual mortality increased from $54 \%$ to $100 \%$ when instantaneous fishing mortality increased from 0.38 to 0.39 . For recreational fishing mortality, total annual mortality increased from $58 \%$ to $99 \%$ when instantaneous fishing mortality increased from 0.49 to 0.50 . These drastic increases in total annual mortality occurred because of a strong density-dependent increase in the sea lamprey mortality rate. Before sea lampreys colonized Lake Superior, lake trout abundance declined as fishing pressure increased (Hile et al. 1951). Then, after sea lampreys colonized the lake, lake trout abundance declined rapidly despite reduced fishing effort (Pycha and King 1975) because sea lamprey predation was the predominant source of mortality on lake trout in Lake Superior, particularly for older fish (Pycha 1980; Swanson and Swedberg 1980). Consequently, my modeling confirms that the historical collapse of lake trout in Lake Superior was likely caused by fishing mortality that drove lake trout stocks to a low abundance where the proportion of the population killed by sea lampreys increased sharply and thereby drove the population to near extinction. 


\section{MANAGEMENT IMPLICATIONS}

In Lake Superior, fishery managers regulate instantaneous fishing mortality $F$ with harvest quotas and use total annual mortality $A$ to monitor population status. My results suggest that the current total fishing mortality estimate of 0.025 and the current total annual mortality estimate of $34 \%$ are sustainable. The $42 \%$ total annual mortality limit in the Lake Superior lake trout rehabilitation plan also appears to be sustainable (LSLTTC 1986). For commercial gill-net fisheries, my results suggest that fishery managers could set the maximum instantaneous fishing mortality rate at 0.20 to avoid decline, 0.27 to avoid extinction, and 0.38 to avoid extinction within 200 years and then monitor these thresholds using maximum total annual mortality rates of $42 \%$ to avoid decline, $46 \%$ to avoid extinction, and $54 \%$ to avoid extinction within 200 years (Table 3 ). Similarly, for recreational angling fisheries, fishery managers could set the maximum instantaneous fishing mortality rate at 0.29 to avoid decline, 0.33 to avoid extinction, and 0.49 to avoid extinction within 200 years and then monitor these thresholds using maximum total annual mortality rates of $47 \%$ to avoid decline, $49 \%$ to avoid extinction, and 58\% to avoid extinction within 200 years (Table 3). I modeled commercial and recreational fishing mortality separately, but the two fisheries occur simultaneously in WI2. Lake trout abundance, probability of extinction, and time to extinction for a combination of recreational and commercial fishing mortality would be estimated as a value between the extremes observed with only commercial fishing mortality and only recreational fishing mortality. Before instituting the mortality thresholds, my results should be evaluated experimentally to ensure that my simulation results are sustainable. For example, the total allowable catch for commercial fisheries and angling size and bag 
limits could be modified for five years to provide contrast in fishing mortality, while monitoring fish population responses. Later, commercial fishery quotas and angling size and bag limits could be modified in the opposite direction for five years to provide further contrast in fishing mortality, while monitoring fish population responses. Fisheries should continue to be monitored because my results suggest that sea lampreys would decimate the lake trout population if fishing mortality reduces lake trout abundance to a low level. My model results should not be accepted without question because models are simplifications that do not perfectly represent reality (Hall and Day 1977). In the words of Robert H. MacArthur, "A model is a lie that helps you see the truth" (Hansen et al. 1993). Models should not be seen as the final product (Walters 1986), but rather, should be used in conjunction with data to form adaptive management practices to learn about the lake trout fishery in WI2 (Hall and Day 1977; Walters 1986).

My model could be modified to include density-dependent growth and maturity sub-models and to include only adult females as the spawning stock in the stock-recruit sub-model. As abundance decreases, lake trout grow faster, mature younger, and enter fisheries younger. To account for density-dependent changes in growth, a growth submodel could be added to the simulation model to predict density-dependent changes in size at age. To account for density-dependent changes in age at maturity, a maturity submodel could be added to the simulation model to predict density-dependent changes in age at maturity. To more accurately and precisely predict density-dependent changes in recruitment, the recruitment sub-model could be modified to include only female lake trout as the spawning stock. Although these modifications would make the lake trout population model more realistic, the current model gives more conservative estimates of 
maximum sustainable fishing and total mortality rates, because density-dependent responses are compensatory and thereby regulate the population in the direction of the long-term average or equilibrium (Everhart and Youngs 1981; Gotelli 2001). Therefore, as fishing mortality increases, fish populations respond through density-dependent growth and recruitment that tend to maintain the equilibrium level of abundance. In the current model, lake trout mature at a fixed age, so as fishing mortality increases, the adult stock declines and results in recruitment overfishing. In contrast, as fishing mortality increases in a model with density-dependent growth and maturity, fish would grow faster, mature younger, and delay the onset of recruitment overfishing, so the population could sustain higher levels of mortality (Helser and Brodziak 1998). 


\section{REFERENCES}

Baldwin, N. S., R. W. Saalfeld, M. A. Ross, and H. J. Buettner. 1979. Commercial fish production in the Great Lakes, 1867-1977. Great Lakes Fishery Commission, Technical Report 3, Ann Arbor, Michigan.

Bence, J. R., R. A. Bergstedt, G. C. Christie, P. A. Cochran, M. P. Ebener, J. F. Koonce, M. A. Rutter, and W. D. Swink. 2003. Sea lamprey (Petromyzon marinus) parasite-host interactions in the Great Lakes. Journal of Great Lakes Research 29 (Supplement 1):253-282.

Bennett, E. B. 1978. Characteristics of the thermal regime of Lake Superior. Journal of Great Lakes Research 4:310-319.

Berst, A. H., and G. R. Spangler. 1973. Lake Huron: the ecology of the fish community and man's effects on it. Great Lakes Fishery Commission, Technical Report 21, Ann Arbor, Michigan.

Brodziak, J. 2002. In search of optimal harvest rates for West Coast groundfish. North American Journal of Fisheries Management 22:258-271.

Bronte, C. R. 1993. Evidence of spring spawning lake trout in Lake Superior. Journal of Great Lakes Research 19:625-629.

Bronte, C. R., S. T. Schram, J. H. Selgeby, and B. L. Swanson. 1995. Densityindependent survival of wild lake trout in the Apostle Islands area of Lake Superior. Journal of Great Lakes Research 21 (Supplement 1):246-252. 
Burnham-Curtis, M. K., and G. R. Smith. 1994. Osteological evidence of genetic divergence of lake trout (Salvelinus namaycush) in Lake Superior. Copeia 4:843850.

Busiahn, T. R., editor. 1990. Fish community objectives for Lake Superior. Great Lakes Fishery Commission, Special Publication 90-1, Ann Arbor, Michigan.

Campana, S. E., W. Joyce, L. Marks, L. J. Natanson, N. E. Kohler, C. F. Jensen, J. J. Mello, H. L. Pratt, Jr., and S. Myklevoll. 2002. Population dynamics of the porbeagle in the northwest Atlantic Ocean. North American Journal of Fisheries Management 22:106-121.

Christie, W. J. 1973. A review of the changes in the fish species composition of Lake Ontario. Great Lakes Fishery Commission, Technical Report 23, Ann Arbor, Michigan.

Cornelius, F. C., K. M. Muth, and R. Kenyon. 1995. Lake trout rehabilitation in Lake Erie: a case history. Journal of Great Lakes Research 21 (Supplement 1):65-82.

Corradin, L. M. 2004. Recruitment and growth dynamics of lake trout in western Lake Superior. Master's thesis. University of Wisconsin - Stevens Point.

Cross, P. C., and S. R. Beissinger. 2001. Using logistic regression to analyze the sensitivity of PVA models: a comparison of methods based on African wild dog models. Conservation Biology 15:1335-1346.

Dale, B. W., L. G. Adams, and R. T. Bowyer. 1994. Functional response of wolves preying on barren-ground caribou in a multiple-prey ecosystem. Journal of Animal Ecology 63:644-652. 
Ellner, S. P., and J. Fieberg. 2003. Using PVA for management despite uncertainty: effects of habitat, hatcheries, and harvest on salmon. Ecology 84:1359-1369.

Elrod, J. H., R. O'Gorman, C. P. Schneider, T. H. Eckert, T. Schaner, J. N. Bowlby, and L. P. Schleen. 1995. Lake trout rehabilitation in Lake Ontario. Journal of Great Lakes Research 21 (Supplement 1):83-107.

Eschmeyer, P. H. 1955. The reproduction of lake trout in southern Lake Superior. Transactions of the American Fisheries Society 84:47-74.

Essington, T. E. 2003. Development and sensitivity analysis of bioenergetics models for skipjack tuna and albacore: a comparison of alternative life histories. Transactions of the American Fisheries Society 132:759-770.

Everhart, W.H., and W.D. Youngs. 1981. Principles of Fishery Science. Cornell University Press, Ithaca, New York.

Goodier, J. L. 1981. Native lake trout (Salvelinus namaycush) stocks in the Canadian waters of Lake Superior prior to 1955. Canadian Journal of Fisheries and Aquatic Sciences 38:1724-1737.

Goodier, J. L. 1989. Fishermen and their trade on Canadian Lake Superior: one hundred years. Inland Seas 45:284-306.

Gotelli, N. J. 2001. A primer of ecology, $3^{\text {rd }}$ edition. Sinauer Associates, Sunderland, Massachusetts.

Haddon, M. 2001. Modelling and quantitative methods in fisheries. Chapman and Hall/CRC, Boca Raton, Florida. 
Hall, C. A. S., and J. W. Day, Jr. 1977. Systems and models: terms and basic principles. Pages 5-36 in C. A. S. Hall and J. W. Day, Jr., editors. Ecosystem modeling in theory and practice: an introduction with case histories. John Wiley and Sons, New York.

Hansen, M. J., editor. 1990. Lake Superior: the state of the lake in 1989. Great Lakes Fishery Commission, Special Publication 90-3, Ann Arbor, Michigan.

Hansen, M. J., editor. 1994. The state of Lake Superior in 1992. Great Lakes Fishery Commission, Special Publication 94-1, Ann Arbor, Michigan.

Hansen, M. J., editor. 1996. A lake trout restoration plan for Lake Superior. Great Lakes Fishery Commission, Miscellaneous Publication, Ann Arbor, Michigan.

Hansen, M. J. 1999. Lake trout in the Great Lakes: basinwide stock collapse and binational restoration. Pages 417-453 in W. W. Taylor and C. P. Ferreri, editors. Great Lakes fisheries policy and management: a binational perspective. Michigan State University Press, East Lansing.

Hansen, M. J., D. Boisclair, S. B. Brandt, S. W. Hewett, J. F. Kitchell, M. C. Lucas, and J. J. Ney. 1993. Applications of bioenergetics models to fish ecology and management: where do we go from here? Transactions of the American Fisheries Society 122:1019-1030.

Hansen, M. J., M. P. Ebener, R. G. Schorfhaar, S. T. Schram, D. R. Schreiner, and J. H. Selgeby. 1994a. Declining survival of lake trout stocked during 1963-1986 in U.S. waters of Lake Superior. North American Journal of Fisheries Management $14: 395-402$. 
Hansen, M. J., M. P. Ebener, R. G. Schorfhaar, S. T. Schram, D. R. Schreiner, J. H. Selgeby, and W. W. Taylor. 1996. Causes of declining survival of lake trout stocked in U.S. waters of Lake Superior in 1963-1986. Transactions of the American Fisheries Society 125:831-843.

Hansen, M. J., M. P. Ebener, J. D. Shively, and B. L. Swanson. 1994b. Lake trout. Pages 13-34 in M. J. Hansen, editor. The state of Lake Superior in 1992. Great Lakes Fishery Commission, Special Publication 94-1, Ann Arbor, Michigan.

Hansen, M. J., J. W. Peck, R. G. Schorfhaar, J. H. Selgeby, D. R. Schreiner, S. T. Schram, B. L. Swanson, W. R. MacCallum, M. K. Burnham-Curtis, G. L. Curtis, J. W. Heinrich, and R. J. Young. 1995. Lake trout (Salvelinus namaycush) populations in Lake Superior and their restoration in 1959-1993. Journal of Great Lakes Research 21 (Supplement 1):152-175.

Hanson, L. H, and P. J. Manion. 1978. Chemosterilization of the sea lamprey (Petromyzon marinus). Great Lakes Fishery Commission, Technical Report 29, Ann Arbor, Michigan.

Hanson, L. H, and P. J. Manion. 1980. Sterility method of pest control and its potential role in an integrated sea lamprey (Petromyzon marinus) control program. Canadian Journal of Fisheries and Aquatic Sciences 37:2108-2117.

Healey, M. C. 1978. The dynamics of exploited lake trout populations and implications for management. Journal of Wildlife Management 42:307-328.

Helser, T. E., and J. K. T. Brodziak. 1998. Impacts of density-dependent growth and maturation on assessment advice to rebuild depleted U.S. silver hake (Merluccius 
bilinearis) stocks. Canadian Journal of Fisheries and Aquatic Sciences 55:882892.

Hile, R., P. H. Eschmeyer, and G. F. Lunger. 1951. Status of the lake trout fishery in Lake Superior. Transactions of the American Fisheries Society 80:278-312.

Holling, C. S. 1959a. The components of predation as revealed by a study of smallmammal predation of the European pine sawfly. Canadian Entomologist 91:293320.

Holling, C. S. 1959b. Some characteristics of simple types of predation and parasitism. Canadian Entomologist 91:385-398.

Horns, W. H., C. R. Bronte, T. R. Busiahn, M. P. Ebener, R. L. Eshenroder, T. Gorenflo, N. Kmiecik, W. Mattes, J. W. Peck, M. Petzold, and D. R. Schreiner. 2003. Fishcommunity objectives for Lake Superior. Great Lakes Fishery Commission, Special Publication 03-01, Ann Arbor, Michigan.

Johnson, N. S., M. J. Siefkes, and W. Li. 2005. Capture of ovulating female sea lampreys in traps baited with spermiating male sea lampreys. North American Journal of Fisheries Management 25:67-72.

Khan, N. Y., and S. U. Qadri. 1970. Morphological differences in Lake Superior lake char. Journal of the Fisheries Research Board of Canada 27:161-167.

Kitchell, J. F., and J. E. Breck. 1980. Bioenergetics model and foraging hypothesis for sea lamprey (Petromyzon marinus). Canadian Journal of Fisheries and Aquatic Sciences 37:2159-2168. 
Krueger, C. C., B. L. Swanson, and J. H. Selgeby. 1986. Evaluation of hatchery-reared lake trout for reestablishment of populations in the Apostle Islands region of Lake Superior, 1960-84. Pages 93-107 in R. H. Stroud, editor. Fish culture in fisheries management. American Fisheries Society, Fish Culture Section and Fisheries Management Section, Bethesda, Maryland.

Lawrie, A. H. 1978. The fish community of Lake Superior. Journal of Great Lakes Research 4:513-549.

Lawrie, A. H., and J. F. Rahrer. 1972. Lake Superior: effects of exploitation and introductions on the salmonid community. Journal of the Fisheries Research Board of Canada 29:765-776.

Lawrie, A. H., and J. F. Rahrer. 1973. Lake Superior: a case history of the lake and its fisheries. Great Lakes Fishery Commission, Technical Report 19, Ann Arbor, Michigan.

Linton, B. C. 2002. Population dynamics of a recovering lake trout population in Wisconsin waters of Lake Superior, 1980-2001. Master's thesis. University of Wisconsin - Stevens Point.

LSLTTC (Lake Superior Lake Trout Technical Committee). 1986. A lake trout rehabilitation plan for Lake Superior. Pages 47-62 in S.D. Morse, editor. Lake Superior Committee 1986 annual meeting minutes. Great Lakes Fishery Commission, Ann Arbor, Michigan. 
Marmontel, M., S. R. Humphrey, and T. J. O’Shea. 1997. Population viability analysis of the Florida manatee (Trichechus manatus latirostris), 1976-1991. Conservation Biology 11:467-481.

Matheson, D. H., and M. Munawar. 1978. Lake Superior basin and its development. Journal of Great Lakes Research 4:249-263.

McCarthy, M. A., M. A. Burgman, and S. Ferson. 1996. Logistic sensitivity and bounds for extinction risks. Ecological Modelling 86:297-303.

Messier, F. 1994. Ungulate population models with predation: a case study with the North American moose. Ecology 75:478-488.

Munawar, M., and I. F. Munawar. 1978. Phytoplankton of Lake Superior 1973. Journal of Great Lakes Research 4:415-442.

Oro, D., J. S. Aguilar, J. M. Igual, and M. Louzao. 2004. Modelling demography and extinction risk in the endangered Balearic shearwater. Biological Conservation 116:93-102.

Pearce, W. A., R. A. Braem, S. M. Dustin, and J. J. Tibbles. 1980. Sea lamprey (Petromyzon marinus) in the lower Great Lakes. Canadian Journal of Fisheries and Aquatic Sciences 37:1802-1810.

Peck, J. W. 1986. Dynamics of reproduction by hatchery lake trout on a man-made spawning reef. Journal of Great Lakes Research 12:293-303.

Peck, J. W., and S. P. Sitar. 2000. Lake trout assessment and management in Michigan waters of Lake Superior, 1993-97. Michigan Department of Natural Resources, Fisheries Research Report 2053, Lansing. 
Pierce, R. B., C. M. Tomcko, and M. T. Drake. 2003. Population dynamics, trophic interactions, and production of northern pike in a shallow bog lake and their effects on simulated regulation strategies. North American Journal of Fisheries Management 23:323-330.

Pine III, W. E., M. S. Allen, and V. J. Dreitz. 2001. Population viability of the Gulf of Mexico sturgeon: inferences from capture-recapture and age-structured models. Transactions of the American Fisheries Society 130:1164-1174.

Pycha, R. L. 1980. Changes in mortality of lake trout (Salvelinus namaycush) in Michigan waters of Lake Superior in relation to sea lamprey (Petromyzon marinus) predation, 1968-78. Canadian Journal of Fisheries and Aquatic Sciences 37:2063-2073.

Pycha, R. L., and G. R. King. 1975. Changes in the lake trout population of southern Lake Superior in relation to the fishery, the sea lamprey, and stocking, 1950-70. Great Lakes Fishery Commission, Technical Report 28, Ann Arbor, Michigan.

Quinn II, T. J., and R. B. Deriso. 1999. Quantitative fish dynamics. Oxford University Press, New York.

Radtke, K. 2003. Evaluation of the exploitation of Eastern Baltic cod (Gadus morhua callarias L.) stock in 1976-1997. ICES Journal of Marine Science 60:1114-1122.

Rago, P. J., K. A. Sosebee, J. K. T. Brodziak, S. A. Murawski, and E. D. Anderson. 1998. Implications of recent increases in catches on the dynamics of Northwest Atlantic spiny dogfish (Squalus acanthias). Fisheries Research 39:165-181. 
Richards, J. M., M. J. Hansen, C. R. Bronte, and S. P. Sitar. 2004. Recruitment dynamics of the 1971-1991 year-classes of lake trout in Michigan waters of Lake Superior. North American Journal of Fisheries Management 24:475-489.

Ricker, W. E. 1975. Computation and interpretation of biological statistics of fish populations. Fisheries Research Board of Canada, Bulletin 191, Ottawa, Ontario.

Rosen, R. A., D. C. Hales, and D. G. Unkenholz. 1982. Biology and exploitation of paddlefish in the Missouri River below Gavins Point Dam. Transactions of the American Fisheries Society 111:216-222.

Schram, S. T., J. H. Selgeby, C. R. Bronte, and B. L. Swanson. 1995. Population recovery and natural recruitment of lake trout at Gull Island Shoal, Lake Superior, 1964-1992. Journal of Great Lakes Research 21 (Supplement 1): 225-232.

Smith, B. R., J. J. Tibbles, and B. G. H. Johnson. 1974. Control of the sea lamprey (Petromyzon marinus) in Lake Superior, 1953-70. Great Lakes Fishery Commission, Technical Report 26, Ann Arbor, Michigan.

Smith, S. H. 1995. Early changes in the fish community of Lake Ontario. Great Lakes Fishery Commission, Technical Report 60, Ann Arbor, Michigan.

Solomon, M. E. 1949. The natural control of animal populations. Journal of Animal Ecology 18:1-35.

Swanson, B. L., and D. V. Swedberg. 1980. Decline and recovery of the Lake Superior Gull Island Reef lake trout (Salvelinus namaycush) population and the role of sea lamprey (Petromyzon marinus) predation. Canadian Journal of Fisheries and Aquatic Sciences 37:2074-2080. 
Swink, W. D. 1991. Host-size selection by parasitic sea lampreys. Transactions of the American Fisheries Society 120:637-643.

Swink, W. D. 2003. Host selection and lethality of attacks by sea lampreys (Petromyzon marinus) in laboratory studies. Journal of Great Lakes Research 29 (Supplement 1):307-319.

Walters, C. J. 1986. Adaptive management of renewable resources. Macmillan, New York.

Weiler, R. R. 1978. Chemistry of Lake Superior. Journal of Great Lakes Research $4: 370-385$.

Wilberg, M. J., M. J. Hansen, and C. R. Bronte. 2003. Historic and modern abundance of wild lean lake trout in Michigan waters of Lake Superior: implications for restoration goals. North American Journal of Fisheries Management 23:100-108.

Wisconsin State/Tribal Technical Committee. 2005. Recommended maximum lake trout harvest for the Apostle Islands region of Lake Superior for the 2006-2008 fishing years.

Zar, J. H. 1999. Biostatistical analysis, $4^{\text {th }}$ edition. Prentice-Hall, Inc., Upper Saddle River, New Jersey. 
Table 1. Parameters tested in local sensitivity analysis of a lake trout simulation model for eastern Wisconsin waters of Lake Superior.

\begin{tabular}{|c|c|}
\hline Parameter & Parameter Description \\
\hline Baseline & The baseline run for the sensitivity analysis. \\
\hline $\mathrm{F}_{\mathrm{Ci}}$ & The commercial fishing mortality rate input. \\
\hline $\mathrm{F}_{\mathrm{Ri}}$ & The recreational fishing mortality rate input. \\
\hline M & The natural mortality constant value. \\
\hline $\mathrm{M}_{\mathrm{L}}$ beta & The slope parameter of the sea lamprey mortality rate. \\
\hline $\mathrm{M}_{\mathrm{L}}$ alpha & The intercept parameter of the sea lamprey mortality rate. \\
\hline $\mathrm{M}_{\mathrm{L}}$ error & The error term for the sea lamprey mortality rate. \\
\hline S-R alpha & $\begin{array}{l}\text { The density-independent parameter in the Ricker stock-recruitment } \\
\text { curve. }\end{array}$ \\
\hline S-R beta & $\begin{array}{l}\text { The density-dependent parameter in the Ricker stock-recruitment } \\
\text { curve. }\end{array}$ \\
\hline S-R error & The error term for the Ricker stock-recruitment curve. \\
\hline
\end{tabular}


Table 2. Parameter tested, deviation tested, average abundance, lower and upper $95 \%$ of average abundance, and percent difference between the baseline mean and the mean for the parameter deviated for a lake trout simulation model for eastern Wisconsin waters of Lake Superior. The model was run for 1,000 simulations and 200 years for each simulation.

\begin{tabular}{lcrrrc}
\hline Parameter & Deviation & Mean & $\begin{array}{c}\text { Lower } \\
\mathbf{9 5 \%}\end{array}$ & $\begin{array}{c}\text { Upper } \\
\mathbf{9 5 \%}\end{array}$ & $\begin{array}{c}\text { Mean \% } \\
\text { Difference }\end{array}$ \\
\hline Baseline & - & $2,008,109$ & $1,958,399$ & $2,055,788$ & $0.00 \%$ \\
$\mathrm{~F}_{\mathrm{Ci}}$ & $-10 \%$ & $2,003,352$ & $1,951,307$ & $2,053,787$ & $-0.24 \%$ \\
$\mathrm{~F}_{\mathrm{Ci}}$ & $+10 \%$ & $2,009,518$ & $1,956,653$ & $2,057,911$ & $0.07 \%$ \\
$\mathrm{~F}_{\mathrm{Ri}}$ & $-10 \%$ & $2,006,951$ & $1,950,988$ & $2,055,276$ & $-0.06 \%$ \\
$\mathrm{~F}_{\mathrm{Ri}}$ & $+10 \%$ & $2,007,397$ & $1,955,102$ & $2,053,862$ & $-0.04 \%$ \\
$\mathrm{M}$ & $-10 \%$ & $1,976,106$ & $1,911,877$ & $2,033,347$ & $-1.59 \%$ \\
$\mathrm{M}$ & $+10 \%$ & $2,030,763$ & $1,983,278$ & $2,076,517$ & $1.13 \%$ \\
$\mathrm{M}_{\mathrm{L}}$ beta & $-10 \%$ & 0 & 0 & 0 & $-100.00 \%$ \\
$\mathrm{M}_{\mathrm{L}}$ beta & $+10 \%$ & $1,936,685$ & $1,895,131$ & $1,986,301$ & $-3.56 \%$ \\
$\mathrm{M}_{\mathrm{L}}$ alpha & $-10 \%$ & $1,944,591$ & $1,901,462$ & $1,992,007$ & $-3.16 \%$ \\
$\mathrm{M}_{\mathrm{L}}$ alpha & $+10 \%$ & 0 & 0 & 0 & $-100.00 \%$ \\
$\mathrm{M}_{\mathrm{L}}$ error & $-10 \%$ & $2,007,355$ & $1,949,662$ & $2,057,667$ & $-0.04 \%$ \\
$\mathrm{M}_{\mathrm{L}}$ error & $+10 \%$ & $2,006,070$ & $1,959,072$ & $2,055,113$ & $-0.10 \%$ \\
$\mathrm{~S}-\mathrm{R}$ alpha & $-10 \%$ & $1,917,426$ & $1,869,032$ & $1,962,432$ & $-4.52 \%$ \\
$\mathrm{~S}-\mathrm{R}$ alpha & $+10 \%$ & $2,084,664$ & $2,024,774$ & $2,134,523$ & $3.81 \%$ \\
$\mathrm{~S}-\mathrm{R}$ beta & $-10 \%$ & $2,224,010$ & $2,167,556$ & $2,271,082$ & $10.75 \%$ \\
$\mathrm{~S}-\mathrm{R}$ beta & $+10 \%$ & $1,827,268$ & $1,776,787$ & $1,877,572$ & $-9.01 \%$ \\
$\mathrm{~S}-\mathrm{R}$ error & $-10 \%$ & $2,005,953$ & $1,952,810$ & $2,052,051$ & $-0.11 \%$ \\
$\mathrm{~S}-\mathrm{R}$ error & $+10 \%$ & $2,007,669$ & $1,949,433$ & $2,060,515$ & $-0.02 \%$ \\
\hline & & & & &
\end{tabular}


Table 3. Instantaneous fishing mortality rates, $F$, and total annual mortality rates, $A$, for commercial gill-net fishing mortality and recreational angling fishing mortality when mean abundance began to decline, the probability that the population would go extinct rose above zero, and the time until the population went extinct was less than 200 years for the lake trout population in eastern Wisconsin waters of Lake Superior (iterations = $1,000 ;$ time $=200$ years $)$.

\begin{tabular}{lcccc}
\hline & \multicolumn{2}{c}{ Commercial } & \multicolumn{2}{c}{ Recreational } \\
\cline { 2 - 5 } & F & A & F & A \\
\hline Decline & 0.20 & $42 \%$ & 0.29 & $47 \%$ \\
Extinction & 0.27 & $46 \%$ & 0.33 & $49 \%$ \\
Extinction within 200 years & 0.38 & $54 \%$ & 0.49 & $58 \%$ \\
\hline
\end{tabular}




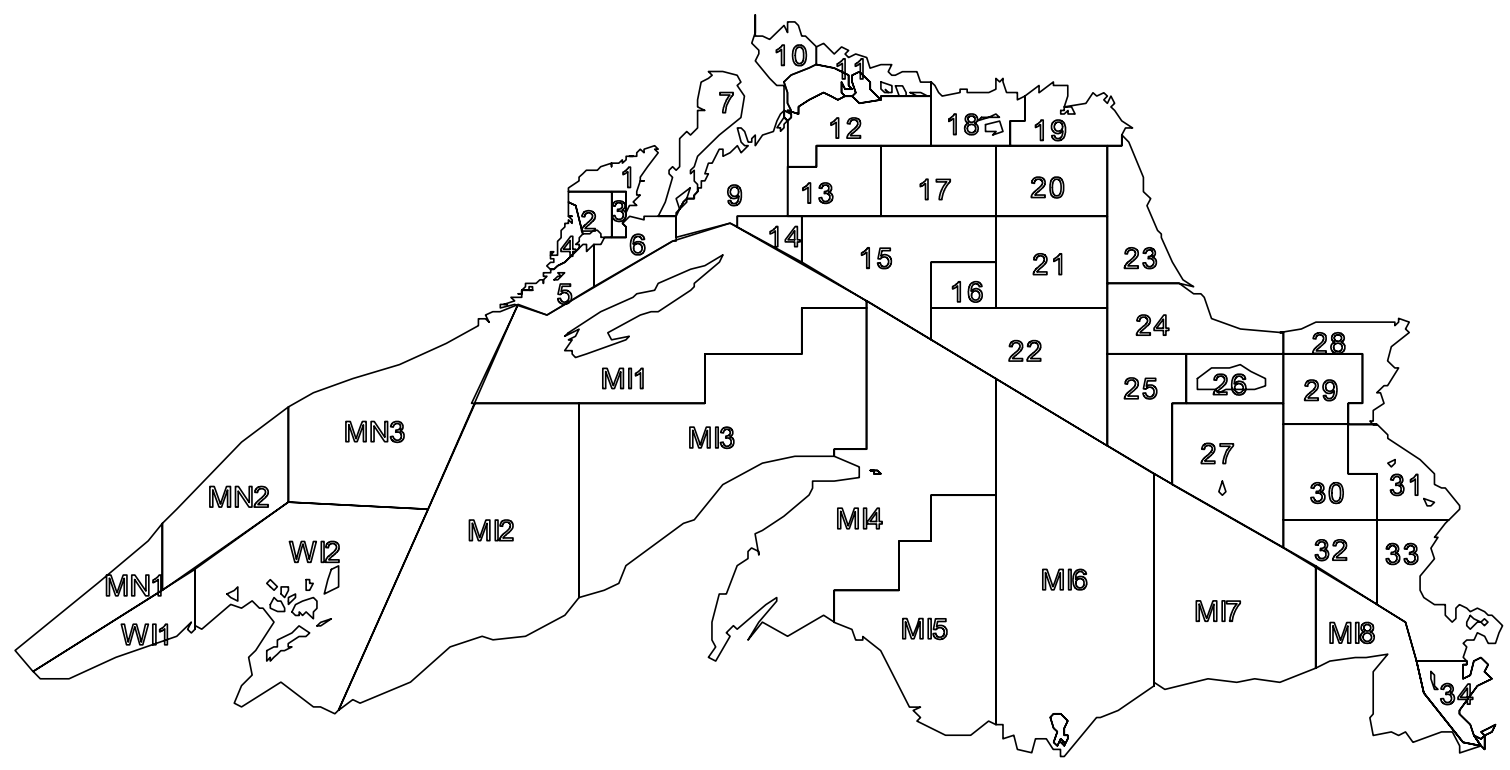

Figure 1. Lake trout management areas in Lake Superior. U.S. management areas are denoted by state: Michigan - MI, Minnesota - MN, and Wisconsin - WI. Canadian management areas are marked using only numbers. 


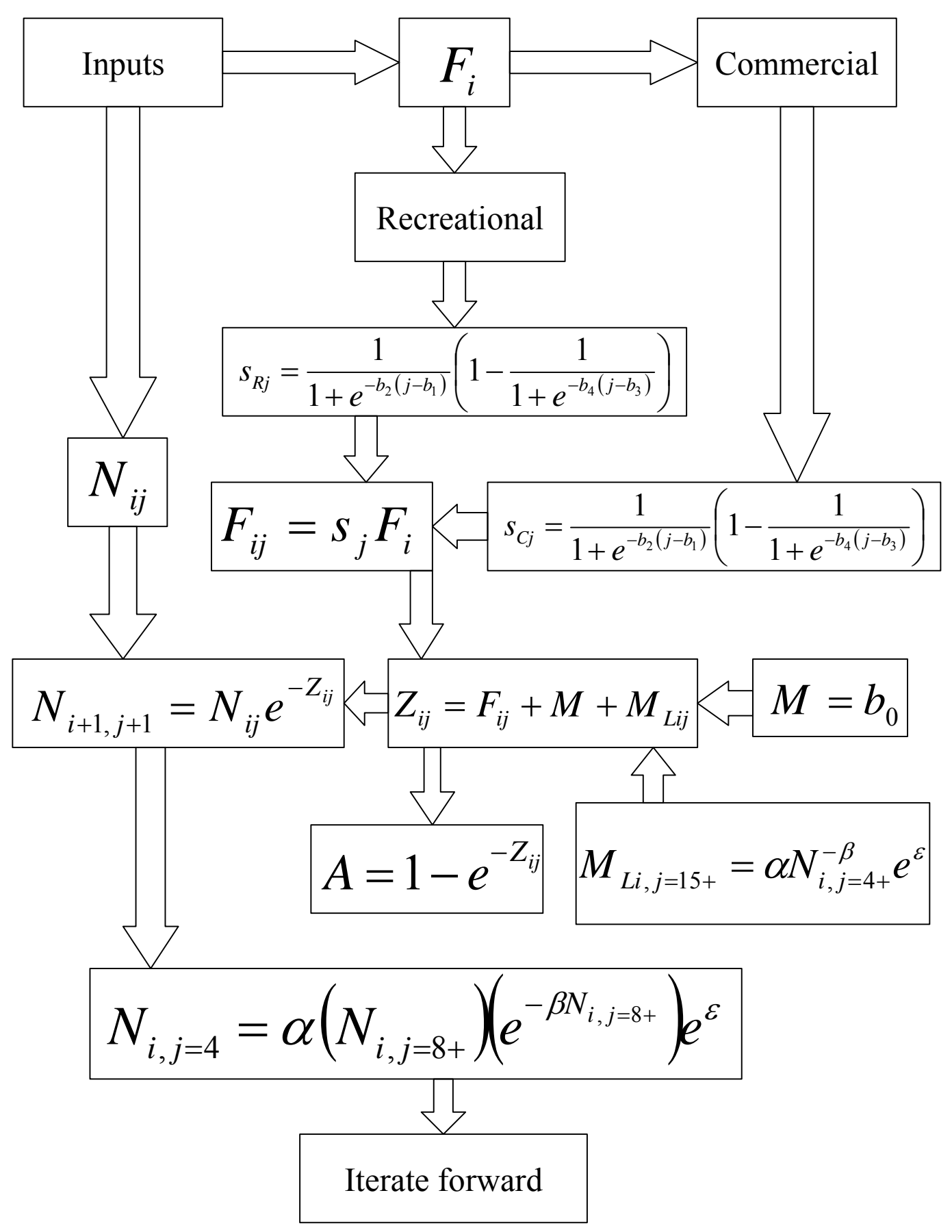

Figure 2. A schematic diagram of a simulation model for lake trout in eastern Wisconsin waters of Lake Superior, where $i$ is year and $j$ is age and inputs are the total instantaneous fishing mortality rate $F_{i}$ in year $i$ and the initial abundance $N_{i j}$ in year $i$ for age $j$. 


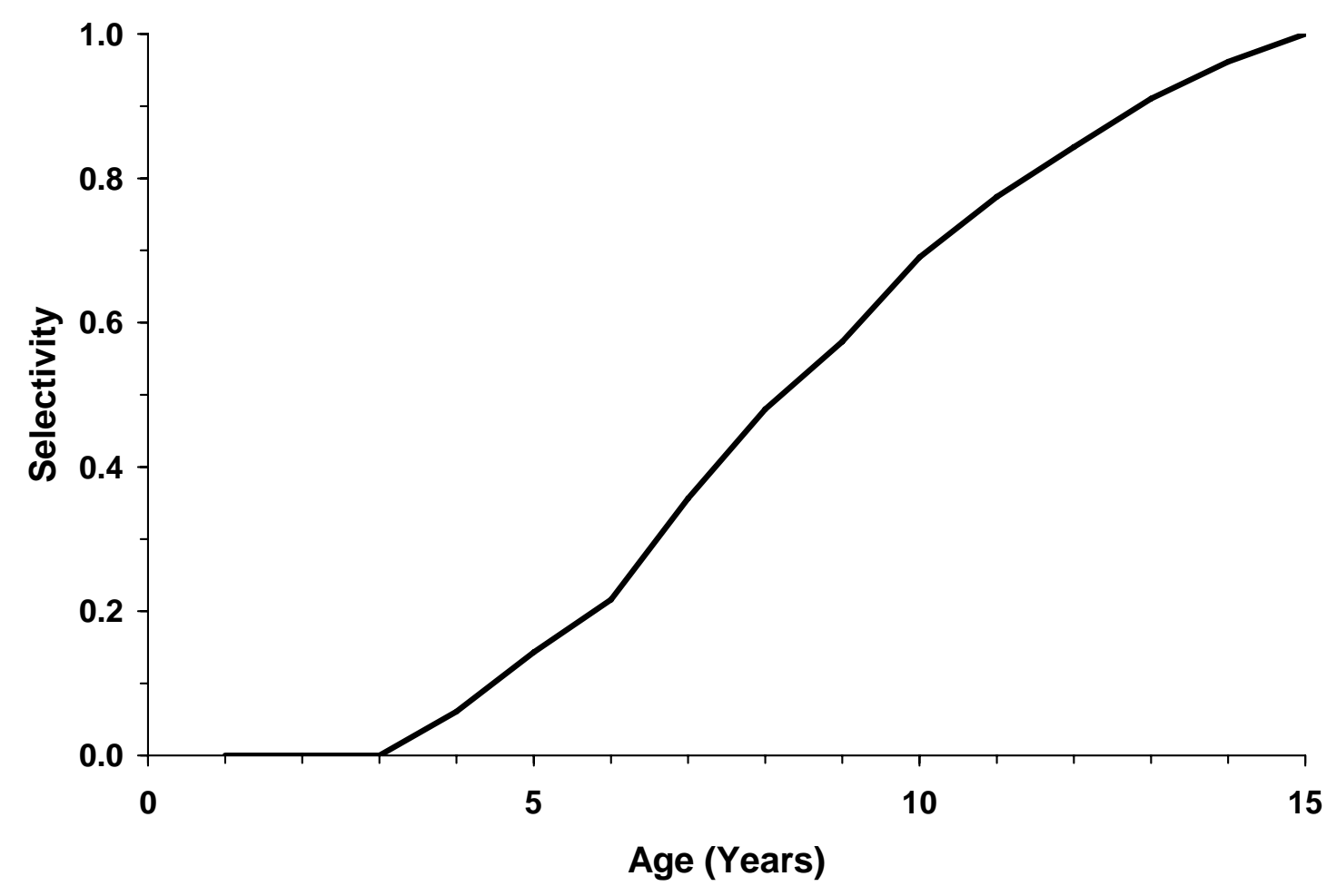

Figure 3. Age-specific selectivity of sea lamprey for lake trout in eastern Wisconsin waters of Lake Superior during 1980-2004. 

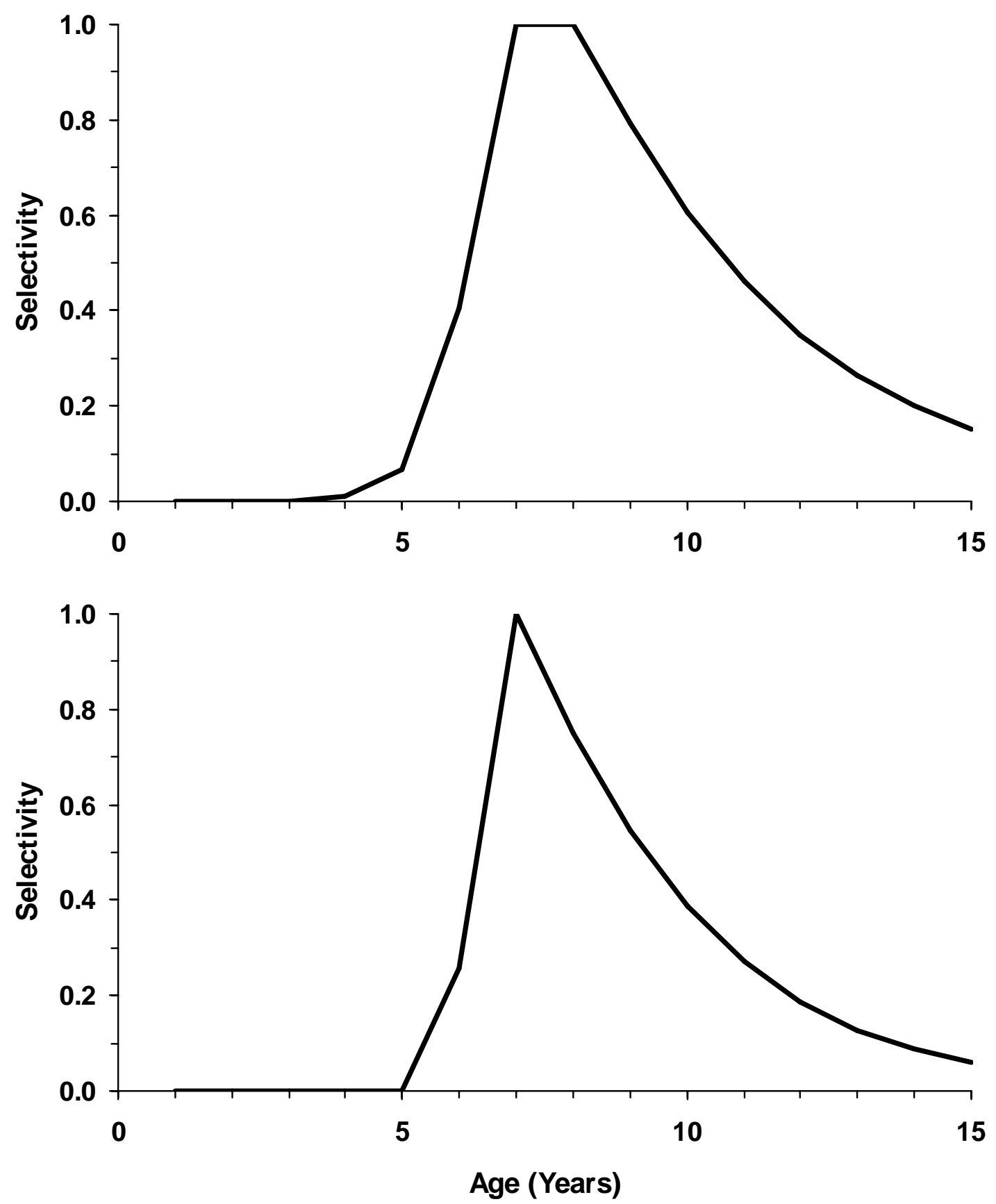

Figure 4. Age-specific selectivity of commercial gill-net fisheries (upper panel) and recreational angling fisheries (lower panel) for lake trout in eastern Wisconsin waters of Lake Superior during 1980-2004. 


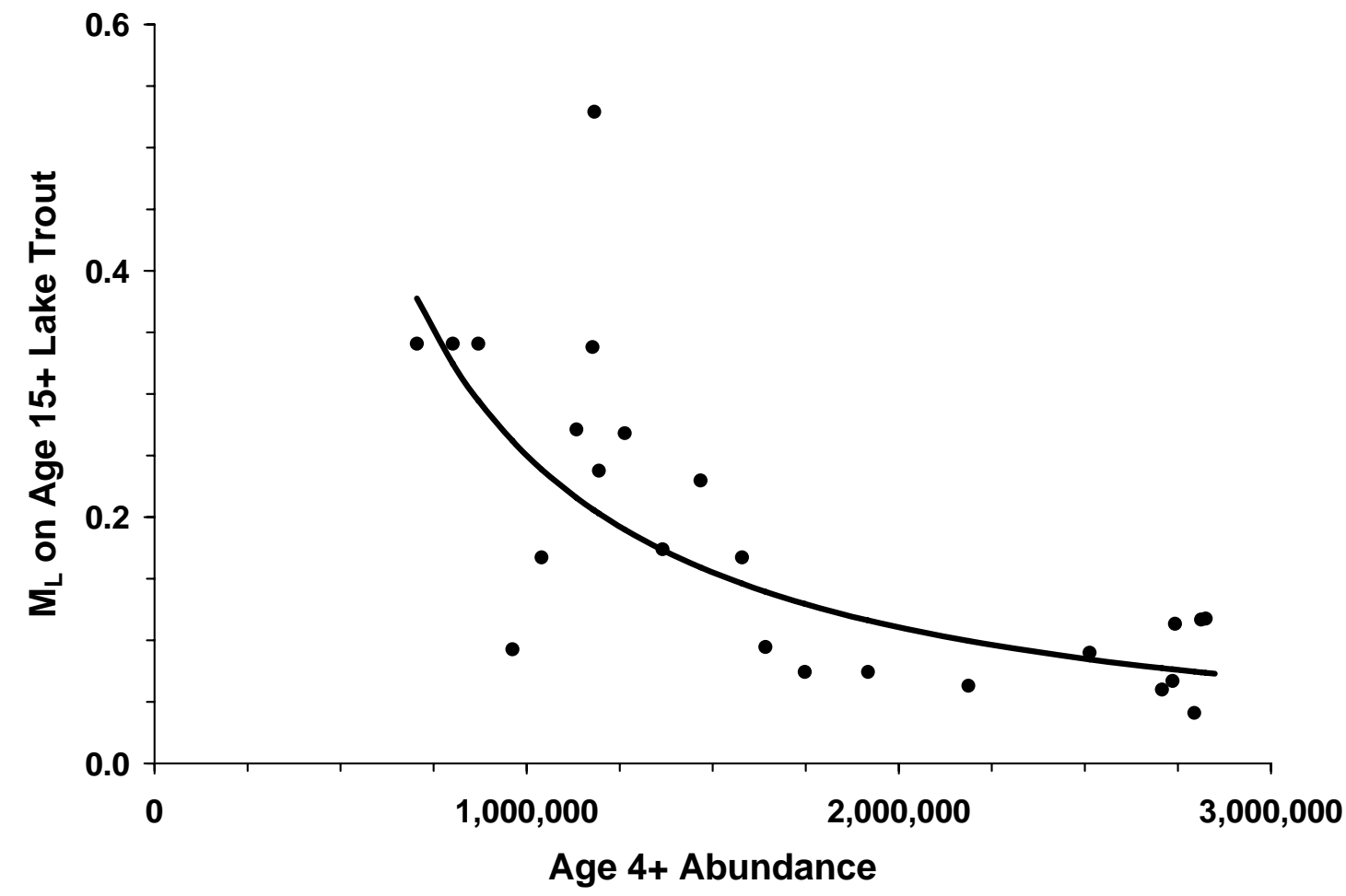

Figure 5. The relationship between instantaneous sea lamprey mortality $\left(M_{L}\right)$ on age15-and-older lake trout and age-4-and-older lake trout abundance in eastern Wisconsin waters of Lake Superior during 1980-2004. 


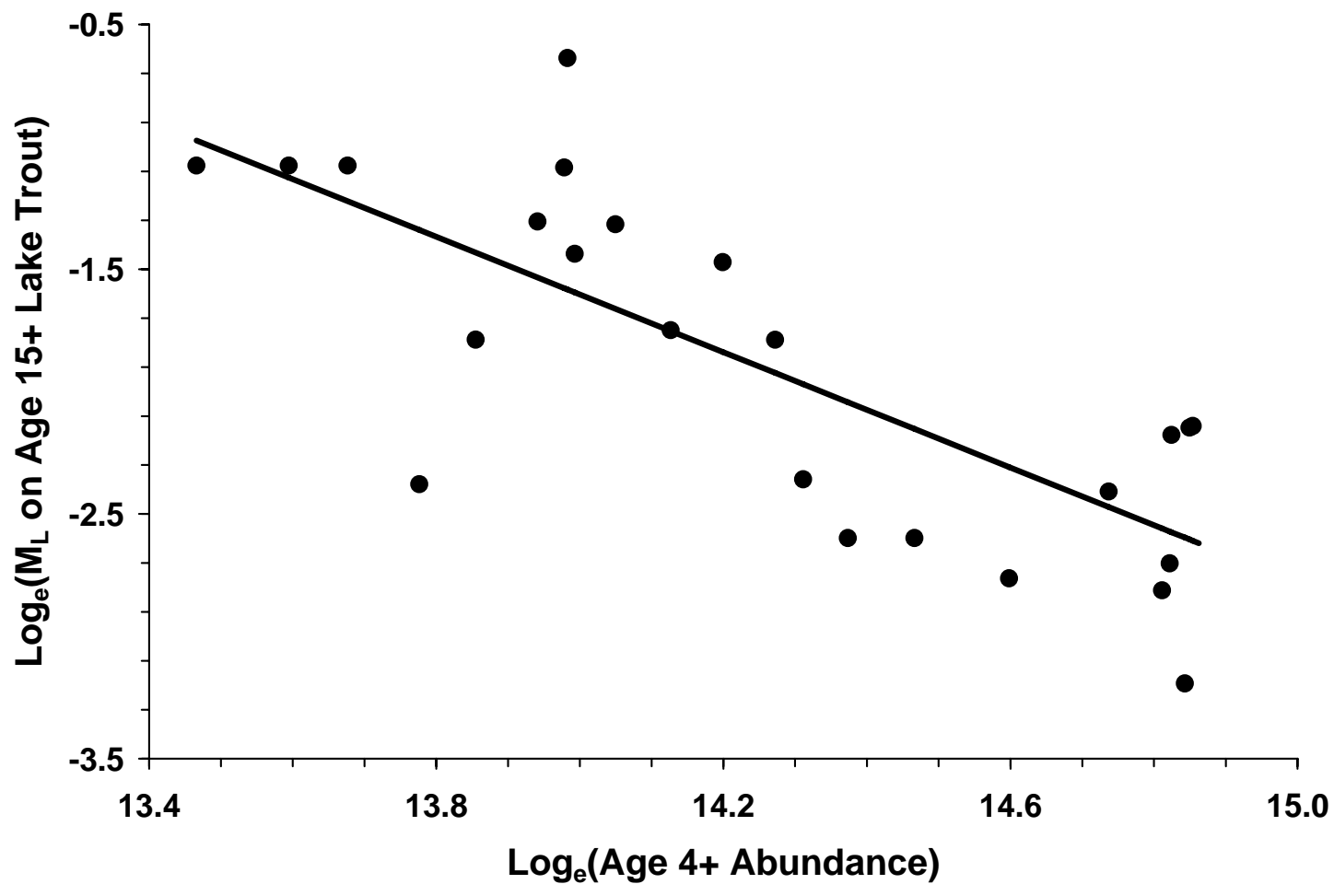

Figure 6. The relationship between the natural logarithm of instantaneous sea lamprey mortality $\left(M_{L}\right)$ on age-15-and-older lake trout and the natural logarithm of age-4-andolder lake trout abundance in eastern Wisconsin waters of Lake Superior during 19802004. 


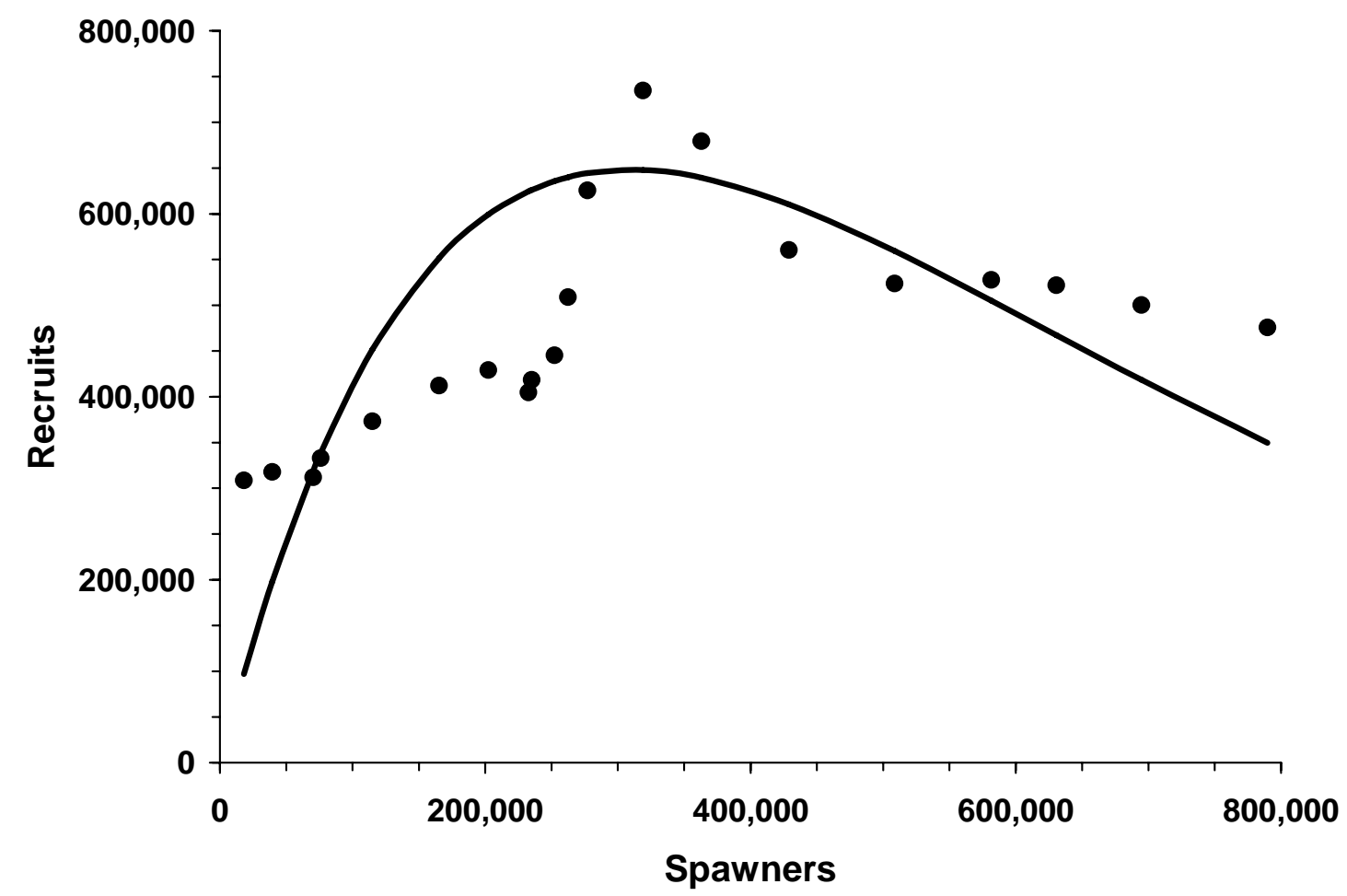

Figure 7. The relationship between number of age-4 lake trout (recruits) and age-8-andolder adult lake trout (spawners) in eastern Wisconsin waters of Lake Superior during 1980-2004. The curve depicts the fitted Ricker stock-recruitment model. 


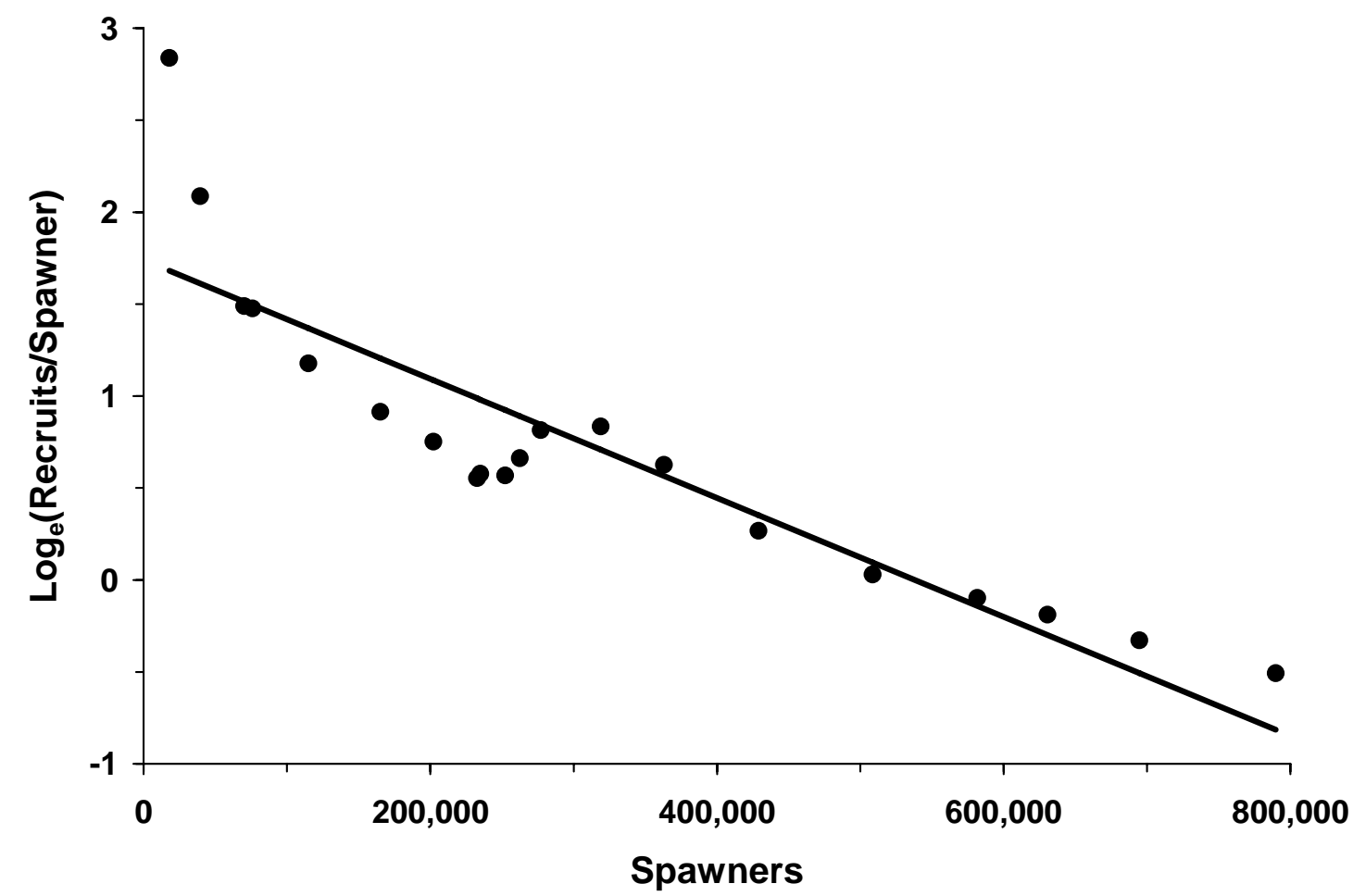

Figure 8 . The relationship between the recruitment rate of age-4 lake trout $\left[\log _{\mathrm{e}}(\right.$ Recruits/Spawner) $]$ and age-8-and-older adult lake trout abundance (spawners) in eastern Wisconsin waters of Lake Superior during 1980-2004. 

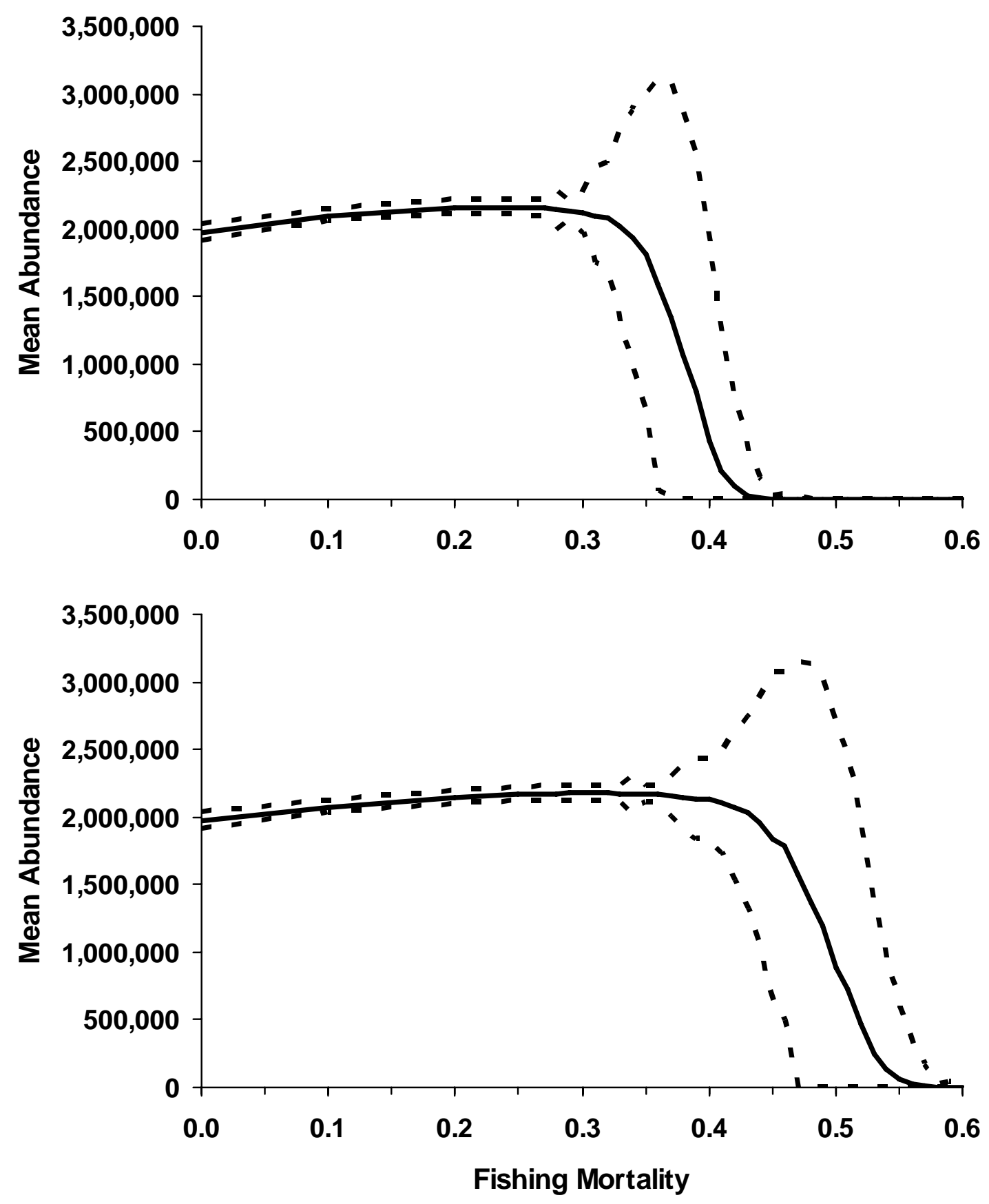

Figure 9. Mean simulated abundance of age- 4 -and-older lake trout $( \pm 95 \%$ confidence interval) versus commercial gill-net fishing mortality (upper panel) and recreational angling fishing mortality (lower panel) in eastern Wisconsin waters of Lake Superior (iterations $=1,000 ;$ time $=200$ years). 

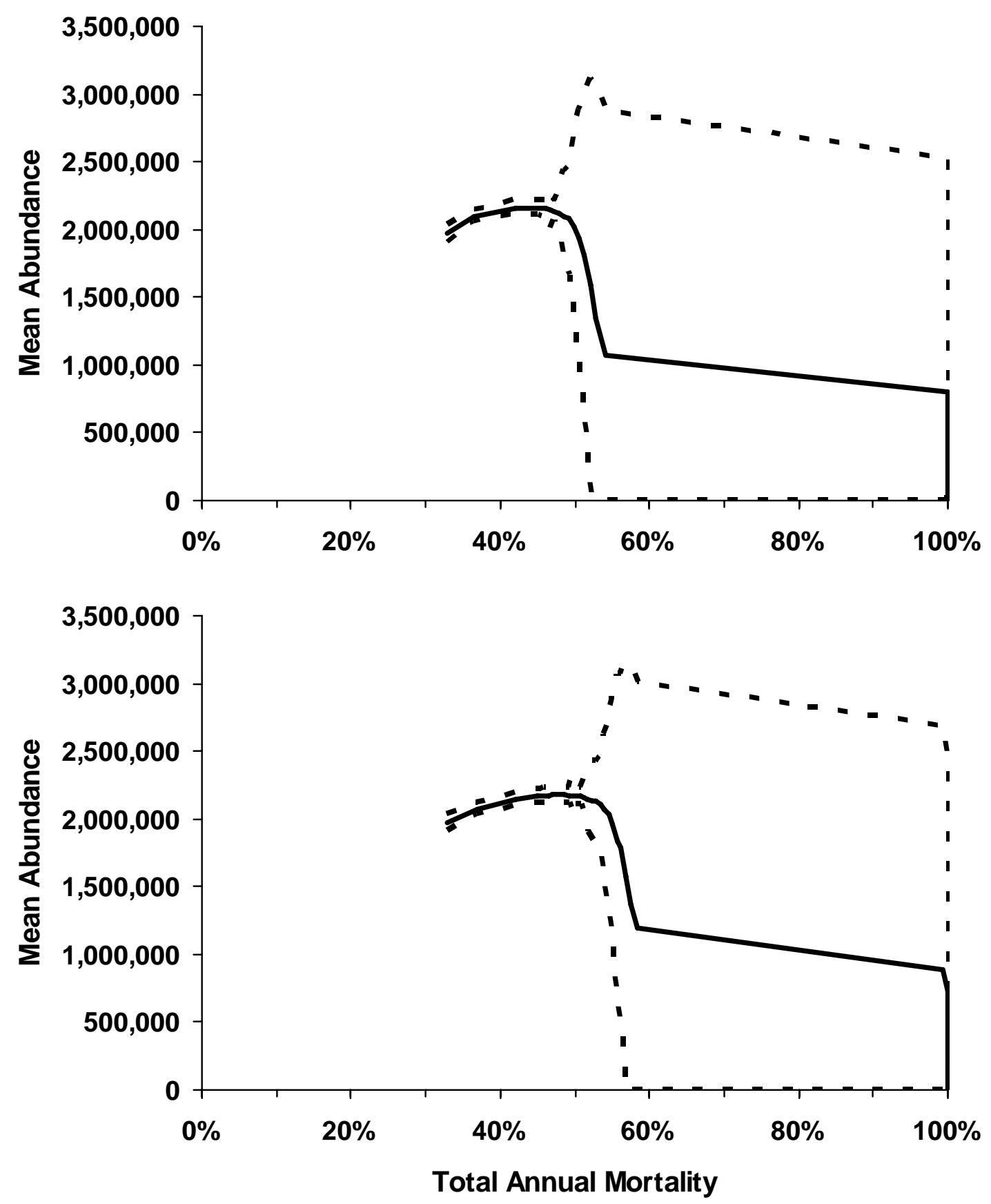

Figure 10. Mean simulated abundance of age-4-and-older lake trout $( \pm 95 \%$ confidence interval) versus median total annual mortality rate for commercial gill-net fishing mortality (upper panel) and recreational angling fishing mortality (lower panel) in eastern Wisconsin waters of Lake Superior (iterations $=1,000$; time $=200$ years). 

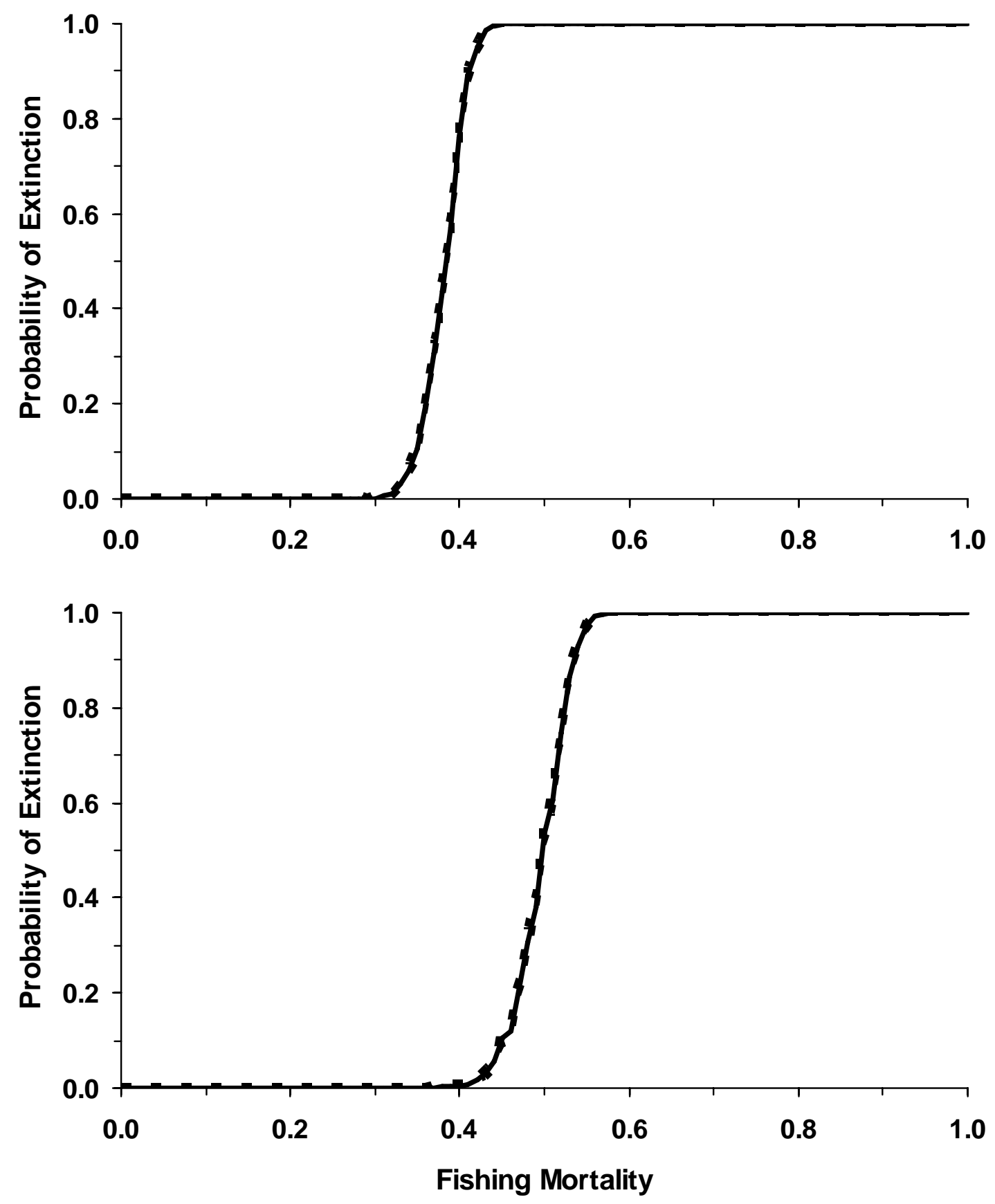

Figure 11. Probability of extinction $( \pm 95 \%$ confidence interval) versus commercial gillnet fishing mortality (upper panel) and recreational angling fishing mortality (lower panel) for the lake trout population in eastern Wisconsin waters of Lake Superior (iterations = $1,000 ;$ time $=200$ years $)$ 

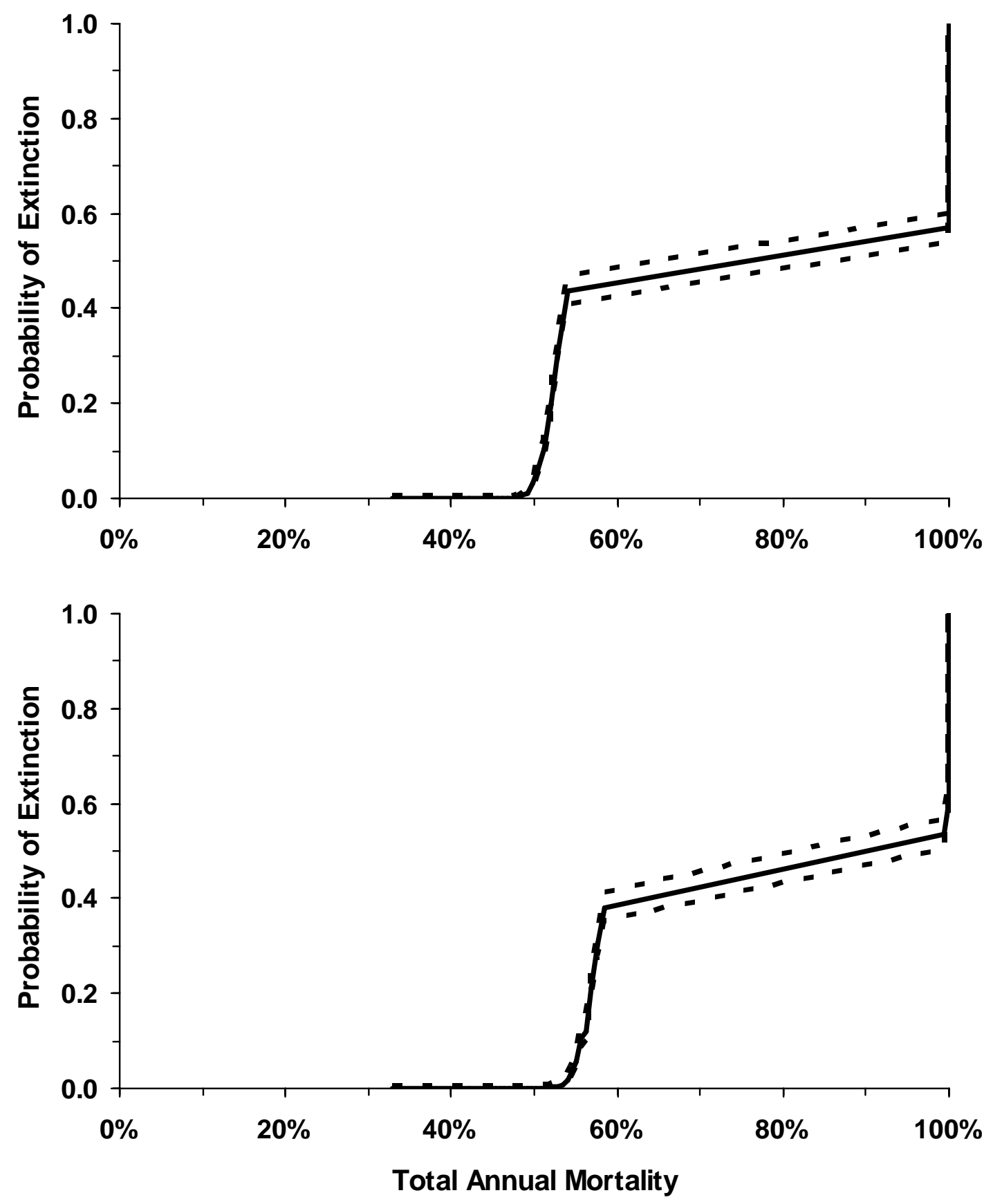

Figure 12. Probability of extinction $( \pm 95 \%$ confidence interval) versus the median total annual mortality rate for commercial gill-net fishing mortality (upper panel) and recreational angling fishing mortality (lower panel) for the lake trout population in eastern Wisconsin waters of Lake Superior (iterations $=1,000$; time $=200$ years). 

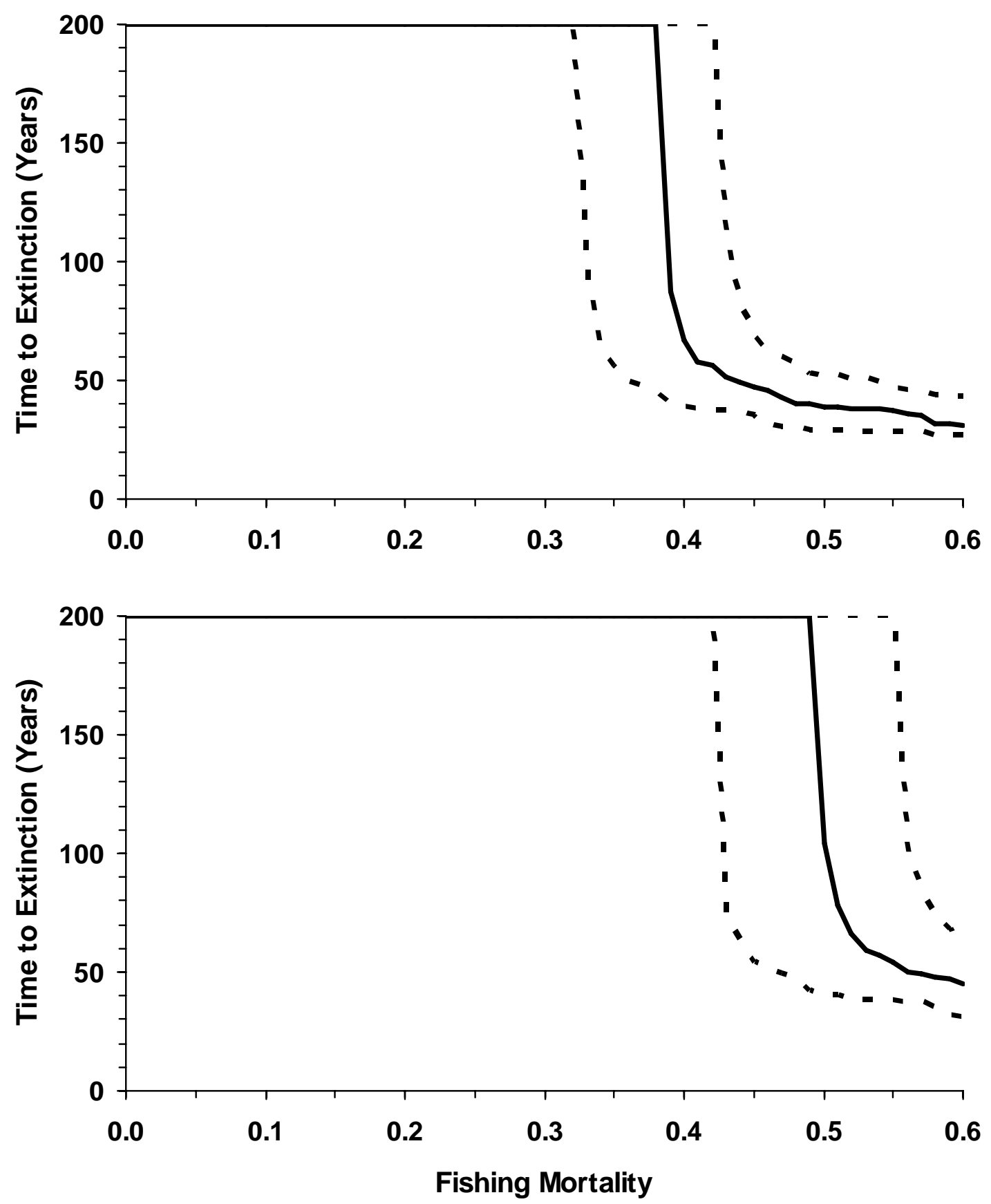

Figure 13. Time to extinction $( \pm 95 \%$ confidence interval) versus commercial gill-net fishing mortality (upper panel) and recreational angling fishing mortality (lower panel) for the lake trout population in eastern Wisconsin waters of Lake Superior (iterations $=$ $1,000 ;$ time $=200$ years $)$. 

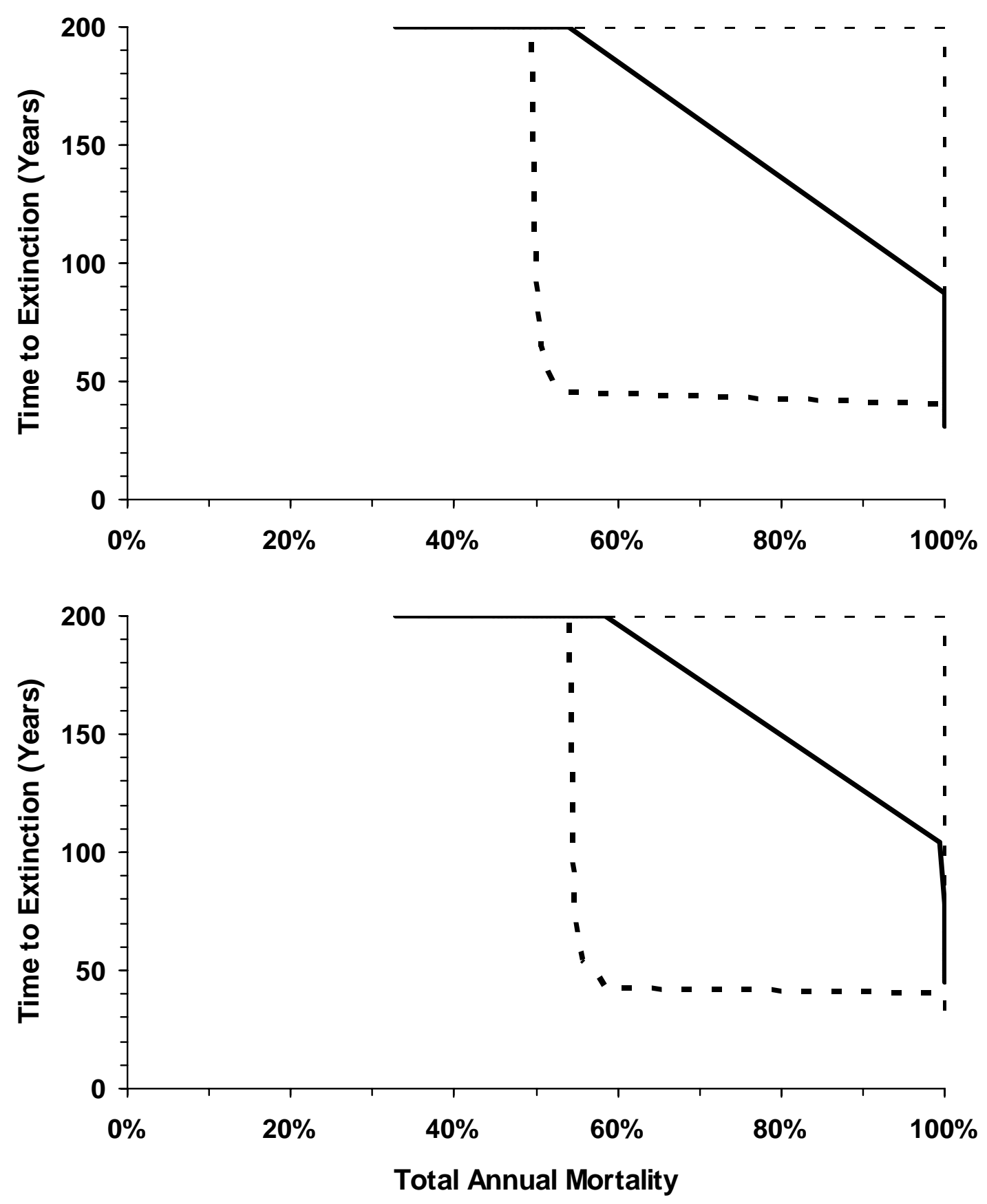

Figure 14. Time to extinction $( \pm 95 \%$ confidence interval) versus the median total annual mortality rate for commercial gill-net fishing mortality (upper panel) and recreational angling fishing mortality (lower panel) for the lake trout population in eastern Wisconsin waters of Lake Superior (iterations $=1,000$; time $=200$ years). 